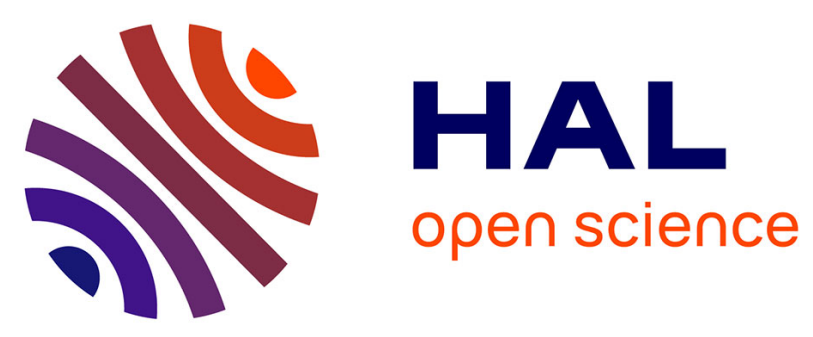

\title{
SNP discovery performance of two second generation sequencing platforms in the NOD2 gene region
}

Espen Melum, Sandra May, Markus Schilhabel, Ingo Thomsen, Tom H. Karlsen, Philip Rosenstiel, Stefan Schreiber, Andre Franke

\section{- To cite this version:}

Espen Melum, Sandra May, Markus Schilhabel, Ingo Thomsen, Tom H. Karlsen, et al.. SNP discovery performance of two second generation sequencing platforms in the NOD2 gene region. Human Mutation, 2010, 31 (7), pp.875. 10.1002/humu.21276 . hal-00552394

\section{HAL Id: hal-00552394 \\ https://hal.science/hal-00552394}

Submitted on 6 Jan 2011

HAL is a multi-disciplinary open access archive for the deposit and dissemination of scientific research documents, whether they are published or not. The documents may come from teaching and research institutions in France or abroad, or from public or private research centers.
L'archive ouverte pluridisciplinaire HAL, est destinée au dépôt et à la diffusion de documents scientifiques de niveau recherche, publiés ou non, émanant des établissements d'enseignement et de recherche français ou étrangers, des laboratoires publics ou privés. 


\section{Human Mutation}

WILEY

\section{SNP discovery performance of two second generation sequencing platforms in the NOD2 gene region}

\begin{tabular}{|c|c|}
\hline Journal: & Human Mutation \\
\hline Manuscript ID: & humu-2009-0537.R2 \\
\hline Wiley - Manuscript type: & Methods \\
\hline $\begin{array}{r}\text { Date Submitted by the } \\
\text { Author: }\end{array}$ & 16-Apr-2010 \\
\hline Complete List of Authors: & $\begin{array}{l}\text { Melum, Espen; Christian-Albrechts-University Kiel, Institute of } \\
\text { Clinical Molecular Biology; Rikshospitalet, Oslo University Hospital, } \\
\text { Medical Department } \\
\text { May, Sandra; Christian-Albrechts-University Kiel, Institute of } \\
\text { Clinical Molecular Biology } \\
\text { Schilhabel, Markus; Christian-Albrechts-University Kiel, Institute of } \\
\text { Clinical Molecular Biology } \\
\text { Thomsen, Ingo; Christian-Albrechts-University Kiel, Institute of } \\
\text { Clinical Molecular Biology } \\
\text { Karlsen, Tom; Rikshospitalet, Oslo University Hospital, Medical } \\
\text { Department } \\
\text { Rosenstiel, Philip; Christian-Albrechts-University Kiel, Institute of } \\
\text { Clinical Molecular Biology } \\
\text { Schreiber, Stefan; Christian-Albrechts-University Kiel, Institute of } \\
\text { Clinical Molecular Biology; University Clinic S.-H. (Campus Kiel), 1st } \\
\text { Medical Department } \\
\text { Franke, Andre; Christian-Albrechts-University Kiel, Institute of } \\
\text { Clinical Molecular Biology }\end{array}$ \\
\hline Key Words: & $\begin{array}{l}\text { Second generation sequencing, SOLiD, 454/FLX, NOD2, rare } \\
\text { variants, benchmarking, coverage simulation, SNP discovery, } \\
\text { mutation detection }\end{array}$ \\
\hline
\end{tabular}

\section{s) ScholaroNE \\ Manuscript Central}


SNP discovery performance of two second generation sequencing platforms in the NOD2 gene region

Short title: NOD2 second generation sequencing

Espen Melum ${ }^{1,2}$, Sandra May ${ }^{1}$, Markus B. Schilhabel ${ }^{1}$, Ingo Thomsen ${ }^{1}$, Tom H. Karlsen ${ }^{2}$, Philip Rosenstiel ${ }^{1}$, Stefan Schreiber ${ }^{1,3}$ and Andre Franke ${ }^{1, \mathbb{I}}$

${ }^{1}$ Institute of Clinical Molecular Biology, Christian-Albrechts-University Kiel, Kiel, Germany

${ }^{2}$ Norwegian PSC Research Center, Clinic for specialized Medicine and Surgery, Oslo University Hospital Rikshospitalet, Oslo, Norway

${ }^{3} 1^{\text {st }}$ Medical Department, University Clinic S.-H. (Campus Kiel), Kiel, Germany

${ }^{\text {II }}$ Corresponding author:

Andre Franke

Institute of Clinical Molecular Biology

Christian-Albrechts University Kiel

Schittenhelmstr. 12

D-24105 Kiel

Germany

e-mail: a.franke@mucosa.de

Tel.: +49 (0) 431-5974138

Fax: +49 (0) 431-597 2196 
Keywords: Second generation sequencing, SOLiD, 454/FLX, NOD2, rare variants, benchmarking, coverage simulation, SNP discovery, mutation detection

\author{
Abbreviations \\ SNP - Single Nucleotide Polymorphism \\ GWAS - Genome-Wide Association Studies \\ CD - Crohn's Disease \\ NOD2 - Nucleotide-binding Oligomerization Domain containing 2 \\ PCR - Polymerase Chain Reaction \\ LR-PCR - Long-Range PCR
}




\section{Introduction}

During the last years, second generation sequencing technologies have made it possible to sequence genetic regions and complete genomes in a time-efficient manner with a low perbase cost (Schuster, 2008). Second generation sequencing has been applied to de novo sequencing of bacterial genomes (Margulies et al., 2005), resequencing of entire human genomes (Bentley et al., 2008; Wang et al., 2008; Wheeler et al., 2008), and exome sequencing (Choi et al., 2009; Ng et al., 2009). An equally important application of this technology is targeted resequencing of (entire) known susceptibility genes or loci of interest, as has been reported for Type I diabetes (Nejentsev et al., 2009). The number of wellestablished disease genes in complex diseases is currently growing at an unprecedented speed, after several hundred genome-wide association studies (GWAS) have been performed for different diseases and other human phenotypes (Hindorff et al., 2009). Crohn's disease (OMIM 266600, CD), besides ulcerative colitis, is one of the two major inflammatory bowel disease phenotypes (Loftus, 2004). In CD, the GWAS method has been especially successful, and to this end, more than 40 new disease genes have been identified (Franke et al., 2007; Parkes et al., 2007; Raelson et al., 2007; Barrett et al., 2008). CD associated variants in the nucleotide-binding oligomerization domain containing 2 (NOD2) gene (OMIM 605956) were well-known before GWAS (Hugot et al., 2001; Ogura et al., 2001), and have been widely replicated (Schreiber et al., 2005).

The SOLiD platform from Applied Biosystems (Foster City, CA, USA) follows the sequencing by ligation approach while the 454/FLX platform from Roche / 454 Life Sciences (Branford, CT, USA) uses the sequencing by synthesis principle (Shendure and Ji, 2008). The new sequencing methods contrast sequencing with end-termination chemistry which has been 
the standard method for sequencing since the original publication by Sanger et al. in 1977 (Sanger et al., 1977). The method used in the 454/FLX system was first published in 2005, in a study reporting on shotgun de novo sequencing of Mycoplasma genitalium (Margulies et al., 2005), and has been further developed with increasing read lengths, throughput and accuracy (Droege and Hill, 2008). The SOLiD system was released commercially in 2007 by Applied Biosystems. Since then, the sequencing protocols and the analytical tools have been substantially improved and extended to approach new scientific questions. The 454/FLX and SOLiD system share several characteristics. With both systems short DNA templates are attached to a surface of beads, and on these beads an emulsion based polymerase chain reaction (PCR) takes place (Shendure et al., 2005). The beads, now containing multiple copies of the DNA template, are transferred to a glass plate or into micropores for SOLiD or 454/FLX, respectively. After this step there are substantial differences between the platforms (Metzker, 2010). For the down-stream analyses, the two most important features are the longer read lengths for the 454/FLX (Droege and Hill, 2008) and the inherent error-checking properties of the two-base pair encoding of the SOLiD system (McKernan et al., 2006). The SOLiD system also delivers significantly more sequence output at the cost of shorter reads compared to the 454/FLX system.

In this study, we wanted to explore the utility of these two technologies in targeted sequencing with a focus on single nucleotide polymorphism (SNP) discovery, the most abundant form of variation. For this, we aimed to resequence the entire coding and noncoding regions of the most widely replicated CD-susceptibility gene NOD2 in $11 \mathrm{CD}$ patients. To benchmark this data further, the identified variants were compared to Sanger sequencing data that were generated in parallel for the $40 \mathrm{~kb}$ large NOD2 genomic region. 
Several methods for enrichment of a target region for sequencing exist, including long-range PCR (LR-PCR), array-based enrichment (Summerer et al., 2009) and in-solution enrichment (Gnirke et al., 2009). The latter two exploit hybridization to complementary nucleotide stretches to capture the target regions of interest. For enrichment of the $40 \mathrm{~kb}$ target region in this study, LR-PCR, which is applicable in any lab, was used. LR-PCR is not specifically optimized for any of the sequencing platforms and produces the same input material to both platforms.

The challenges in the present project will largely parallel the challenges that the genetic community faces when the new genes and regions identified through GWAS will be subjected to deep resequencing (Yeager et al., 2008). 


\section{Material and methods}

\section{Selection of samples}

The precise haplotype structure of the NOD2 locus has been described before (Croucher et al., 2003). Using the data generated by Croucher et al. and the same haplotype nomenclature, we selected 11 patients based on the haplotypes generated by the phasing software PHASE 2.1.1 (Stephens et al., 2001) (Supplementary Table S1). These patients were sequenced following the standard protocols for SOLiD mate-pair library, SOLiD fragment library and the 454/FLX platform.

All CD patients were recruited through the $1^{\text {st }}$ Medical Department of General Internal Medicine of the University Clinic Schleswig-Holstein (UK-SH, Campus Kiel, Germany). Clinical, radiological and endoscopic (i.e. type and distribution of lesions) examinations were required to unequivocally confirm the diagnosis of $\mathrm{CD}$, and histological findings had to be confirmative of, or compatible with, the diagnosis. All recruitment protocols were approved by the ethics committee of the UK-SH and participants gave their written, informed consent.

Genomic DNA was extracted from blood using the Invitek kit (Invitek, Berlin, Germany) and each DNA sample was evaluated by gel electrophoresis for the presence of high-molecular weight DNA and normalized to 50-60 ng/ $\mu$ l using Picogreen fluorescent dye (Invitrogen, Carlsbad, CA, USA).

Primer design and optimization for long-range PCR

LR-PCR primers (Table 1) were designed using the Primer3 software (available online at http://frodo.wi.mit.edu/) (Rozen and Skaletsky, 2000), and the HPLC-purified primers were 
ordered from Metabion (Martinsried, Germany). Amplicon sizes varied from $3 \mathrm{~kb}$ to $11 \mathrm{~kb}$, with an average size of $7 \mathrm{~kb}$ (Figure 1). Adjacent amplicons overlapped with $>70$ bases to allow for SNP detection underneath the primer binding sites. The $50 \mu \mathrm{l}$ PCR reactions were performed using $50 \mathrm{ng}$ of human genomic DNA, $1.5 \mu \mathrm{l}(10 \mu \mathrm{M})$ of the forward and the reverse primer, $5 \mu 1$ GeneAmp High Fidelity 10x PCR Buffer (Applied Biosystems), and 2.5 units of GeneAmp High Fidelity Enzyme Mix (Applied Biosystems). Primer optimization was performed for each amplicon on a Biometra Gradient cycler (Biometra, Goettingen, Germany) using the following gradient program: one cycle at $94^{\circ} \mathrm{C}$ for $2 \mathrm{~min}$, followed by 35 cycles $94^{\circ} \mathrm{C}$ for $15 \mathrm{sec}$ (initial denaturation), at gradient of $45-65^{\circ} \mathrm{C}$ for $30 \mathrm{sec}$ (annealing), at $68^{\circ} \mathrm{C}$ for $9 \mathrm{~min}$ (extension), followed by a final extension step at $72^{\circ} \mathrm{C}$ for $7 \mathrm{~min}$.

The PCR products were cleaned up using the Biorobot 8000 (Qiagen, Hilden, Germany) and the Qiaquick purification kit (Qiagen). The amplicons were subsequently quantified using Picogreen and then pooled at an equimolar ratio based on the following formula:

amount of PCR product $[\mathrm{ng}]=\frac{\text { length of the fragment }[\mathrm{bp}] \times \text { amount of input DNA for library }[\mathrm{ng}]}{\text { length of target }[\mathrm{bp}]}$

\section{Second Generation Sequencing}

Three types of libraries were prepared for each sample: 1) SOLiD mate-paired library, 2) SOLiD fragment library and 3) Roche/454 GS-FLX sequencing library. 
A mate-paired library consists of two pieces of target DNA. These pieces of sequence orignates from the two ends of the same DNA fragment. SOLiD mate-pair libraries were constructed with an insert size of approximately $600 \mathrm{bp}$ using $2 \mu \mathrm{g}$ of DNA from the equimolar pooled amplicons. The DNA was sheared to generate fragments with a size of 500$650 \mathrm{bp}$, end-repaired and methylated. Methylation of EcoP15I sites in the target DNA prevented digestion by the methylation-sensitive EcoP15I enzyme. Then, EcoP15I CAP ligation added the EcoP15I CAP adaptors to the sheared and methylated DNA. After the circularization using DNA T4 ligase, EcoP15I cleaved 25-27 bp away from the unmethylated enzyme recognition sites in the CAP adaptors. Following the ECOP15I digestion another end repair of the DNA fragments was carried out and P1 and P2 adaptors were ligated to the ends of the fragments before PCR amplification. Clonal bead populations were prepared in microreactors by a water-in-oil emulsion PCR. The microreactors contained DNA template, PCR reagents, beads and primers. After the PCR reaction, the emulsion was broken with 2butanol and enrichment of the beads containing a library template was performed by hybridization to polystyrene beads containing the complementary sequence of the P2 primer. A 3' modification of the template on the selected beads allowed for covalent binding to a glass slide. On the SOLiD Analyzer the templated beads were combined with the universal sequencing primer, ligase and a large pool of dibase probes. The dibase probes are fluorescently labeled with four dyes, each dye represents four of the sixteen possible dye nucleotide sequences. Complementary probes hybridized to the template sequence and were ligated during the sequencing process. After measurement of the fluorescence the dye was cleaved of. This process was repeated for five cycles. The synthesized strand was thereafter removed and a new primer was hybridized offset by one base and the ligation cycles were 
repeated. This primer reset process was repeated for five cycles providing a dual measurement for each base. Each library was separately sequenced in one of the eight spots of an octant slide.

\section{$\underline{\text { SOLiD fragment run }}$}

Short fragment DNA libraries were generated using $2 \mu \mathrm{g}$ of DNA from the equimolar pooled amplicons and sequenced at Applied Biosystems in Beverly, MA (USA). LR-PCR fragments were sheared by sonication to a size of 150-200 bp. After end-repairing and P1 and P2 adaptor ligation to the resulting fragments, library-amplification was performed. The resulting library contained molecules representing the entire target sequence. Each molecule was clonally amplified on beads in an emulsion PCR. In the emulsion PCR clonal bead populations were generated in water-in-oil microreactors containing template, PCR reagents, primers and beads with sequence complementary to P1 adaptor on the surface. After the library molecules annealed to the beads, the sequence from the P1 adaptor was extended by a polymerase followed by template dissociation. The emulsion was thereafter broken with 2butanol. Enrichment for beads containing a library template was performed by hybridization to polystyrene beads containing the complementary sequence of the P2 primer, and a 3 '-end modification followed to allow attachment of the beads to the glass surface of the sequencing slide. The sequencing was based on the sequential ligation with dye labeled oligonucleotides as described for the SOLiD mate-paired libraries. For the 50bp fragment run each of the 5 primer cycles included 10 ligations of the dye labeled oligonucleotides. Each library was run on an individual spot on a quadrant slide. 


\section{$\underline{\text { Roche GS-FLX }}$}

FLX DNA libraries were generated at Roche Diagnostics in Penzberg (Germany). For each of the 11 samples consisting of equimolar pooled PCR products, $3 \mu \mathrm{g}$ of DNA was used for the library preparation step, following the standard protocol for whole genome libraries. The pooled PCR fragments were nebulized to 400-800 nucleotide fragments. To get blunted ends, end-repair was performed. Then, short adaptors with 10 base identifier tags were ligated to both ends (adaptor A and B), which were used for purification, amplification and sequencing. The input to the emulsion PCR were quantitated library molecules flanked with proper adaptors for amplification and sequencing. According to the manufacturer the library fragments were mixed with beads coated by oligonucleotides complementary to the sequence of adaptor B. The amplification reaction was performed in a water-in-oil emulsion. The forward PCR primer was biotinylated for use later during the enrichment step. The reaction within the droplets of an emulsion resulted in beads carrying clonally amplified DNA fragments. After the emulsion PCR step, the emulsion was broken chemically and the beads were recovered and washed by filtration. During the emulsion PCR a certain fraction of beads that carry no amplified DNA (null beads) were generated. To reduce the percentage of null beads an enrichment step for template beads was performed. Streptavidin-coated magnetic enrichment beads were added to capture the successfully amplified fragments binding only to those which have incorporated the biotinylated primer. The template beads were finally annealed with sequencing primers and mixed with polymerase and cofactors. Then, they were loaded together with "enzyme beads" (sulfurylase and luciferase) and "packing beads" in a PicoTiterplate device and sequenced using a GS-FLX pyrosequencer (Roche/454 Life Science). During the sequencing process nucleotides were flowed sequentially across the 
PicoTiterPlate device. A light signal was generated if the nucleotide was complementary to the template and thus incorporated. The signal intensity at each nucleotide flow indicated the number of nucleotides. If no nucleotide was incorporated, no light signal was generated and the complementary strand was not elongated. A two area gasket was used during the run for maximized output.

\section{Sanger Sequencing}

Ninety-eight PCR amplicons (size range 83-912 bp, average size 529 bp) were constructed for the same NOD2 target region as described above (see Figure 1 for amplicon overview and Supplementary Table S2 for primer sequences). The corresponding PCRs were performed using AmpliTaq Gold Fast PCR Mastermix (Applied Biosystem), primers and $2.5 \mathrm{ng}$ genomic DNA. For all fragments, cycling was performed with an initial denaturation step of $95^{\circ} \mathrm{C}$ for $10 \mathrm{~min}$ to activate the polymerase, followed by 35 cycles of $96^{\circ} \mathrm{C}$ for $6 \mathrm{sec}, 62^{\circ} \mathrm{C}$ for $6 \mathrm{sec}, 68^{\circ} \mathrm{C}$ for $8 \mathrm{sec}$, and a final step of $72^{\circ} \mathrm{C}$ for $10 \mathrm{sec}$. After PCR, the resulting amplicon was used as a target for sequencing with the BigDye Terminator v1.1 Cycle Sequencing Kit, and analyzed using an Applied Biosystems 3730xl Genetic Analyzer.

Matching against the reference sequence and SNP-calling

The reference sequence for the region was acquired from the human reference sequence hg18 assembly (NCBI's build 36) using the UCSC Genome Browser (http://genome.ucsc.edu/). 
The reads from the SOLiD mate-pair runs were matched separately against the reference with the freely available Corona Lite version 4.2.2 software (Applied Biosystems) (http://solidsoftwaretools.com/gf/project/corona/) allowing two mismatches in color-space (2 per $25 \mathrm{bp}$ ) and counting valid adjacent errors as one. After matching the reads against the reference, they were paired in a test procedure allowing mate-pair distances from 0 to $60 \mathrm{~kb}$. The actual ranges of mate-pair distances were determined manually for each individual sample using a histogram of the distances observed. The mate-pair distances observed for all samples were in the range of $260-690$ bp. Pairing of the runs was performed again with these estimated mate-pair distances, and the results of this pairing formed the basis for SNPcalling.

The fragment runs were matched against the reference genome using Corona Lite version 4.2.2, allowing four mismatches in color-space (4 per $50 \mathrm{bp}$ ) and counting valid adjacent errors as one (i.e. allowing on average the same number of mismatches per base sequenced as in the mate-pair procedure). The matched fragment runs were used for SNP-calling.

SNP-calling for the SOLiD data was performed using with Corona Lite version 4.2.2 with default settings for both the mate-pair library and the fragment library.

The 454/FLX runs were mapped against the reference sequence and evaluated for SNPs with the Genome Sequencer FLX Software Package version 2.0.01.12 software from Roche. All of the matched sequences were evaluated for SNPs, and high confidence SNPs reported by the software were considered further. To avoid bias from areas with high coverage, additional 
filtering was applied with the following criteria: base pair positions where between $30 \%$ and $70 \%$ of the reads showed alternative bases were called as heterozygous SNPs, while the basepair positions where more than $70 \%$ of the reads differed from the reference were called as homozygous SNPs. As the objective of the present paper was to evaluate the performance in SNP detection, insertions and deletions were not evaluated.

\begin{abstract}
All SNP positions were looked up in the NCBI's database of SNPs (dbSNP 130) (Sherry et al., 2001) and assigned the respective dbSNP ID ("rs-number") if the SNP had been annotated before. The novel SNPs that were confirmed by Sanger were submitted to dbSNP and their temporary accession numbers were used ("ss-numbers"). The remaining SNPs were assigned the names NOD2_01 to NOD2_12 for this publication. The exact genomic positions of all identified SNPs are shown in Supplementary Table S3.
\end{abstract}

Sanger SNP detection

Semi-automated SNP detection was carried out using the software novoSNP (http://www.molgen.ua.ac.be/bioinfo/novosnp/) (Weckx et al., 2005). All base pair positions where a SNP was reported by the second generation technologies were manually inspected.

\title{
Coverage
}

The achieved coverage was calculated from the number of reads covering a specific base pair position. For the SOLiD platform, the coverage was calculated based on the reads that mapped uniquely (non-unique matches were excluded) to the reference sequence, and paired 
with a mate for the mate-pair library, while the coverage for the 454/FLX platform was calculated based on the reads that aligned to the reference sequence. These coverage figures represent the reads subsequently used for SNP-calling. Coverage depths for individual LRPCR fragments were calculated using the $\mathrm{R}$ statistical package v2.91 (http://www.rproject.org/) and custom scripts. To compare the coverage between the different technologies, the coverage at all base-pair positions were averaged for all the samples and calculated in 100 bp bins.

\section{Coverage simulation}

To compare the performance at lower coverages than the maximum achieved, an in silico experiment with random and sequential removal of reads, aiming for an achieved coverage of 100x, 80x, 60x, 40x, 20x, 10x and 5x, was performed. The random removal of reads was performed irrespective of where in the sequence the read mapped. The benchmarking reference was defined as the genotype call made for the respective technology in the full data set (maximum achieved coverage). In samples where the full achieved coverage was below the aimed coverage in the simulation, the full achieved coverage was used for that simulation step. 


\section{Results}

\section{Sequence content and coverage}

There were substantial differences in the coverage achieved between the different samples (Table 1). The SOLiD mate-pair and fragment runs had fixed read lengths of respectively $2 \times 25 \mathrm{bp}$ and $50 \mathrm{bp}$, while for the 454/FLX technology the read lengths differed with averages from 217 bp to 227 bp in the different samples. For the 454/FLX runs $90 \%$ of the reads were above $133 \mathrm{bp}$ to $177 \mathrm{bp}$ for the different samples. The overall GC content in the sequenced region was $48 \%$ (variation across the region can be seen from Figure 2). Forty-three percent of the sequence consisted of repetitive elements. The coverage varied corresponding to the LR-PCR amplicons for the SOLiD mate-pair and SOLiD fragment library, while for the 454/FLX this was not so pronounced (Figure 2). The per base Pearson's correlation coefficients between the different samples showed a good correlation within each technology, and were on average 0.81 (range 0.32-0.98) for SOLiD mate-pair, 0.88 (range 0.67-0.98) for SOLiD fragment and 0.78 (range 0.63-0.89) for the 454/FLX. Only four samples sequenced with the mate-pair library had more than 10 base pair positions not covered, that was for sample $6,7,8$ and 9 where respectively $0.21 \%, 0.11 \%, 0.26 \%$ and $0.03 \%$ of the base pair positions were not covered. For the fragment library and the 454/FLX none of the samples had more than 10 base pair positions not covered.

\section{SNP detection and Sanger confirmation}

Summarizing all samples, there were a total of 442 SNPs discovered with the SOLiD matepair library, 454 with the SOLiD fragment library and 441 with the 454/FLX (Figure 3). The numbers of homozygous SNPs were 146, 141 and 147 for the mate-pair, fragment and 
454/FLX respectively. Ninety-eight percent of the homozygous SNPs detected with the matepair library, $100 \%$ detected with fragment library and 99\% detected with the 454/FLX were confirmed by Sanger sequencing. Out of the five homozygous SNPs (Mate-pair: 3 SNPs, Fragment: 0 SNPs, 454/FLX: 2 SNPs) not confirmed by Sanger sequencing, four were detected as heterozygous with Sanger, while one SNP identified with the mate-pair library was not detected at all. Calling of this SNP was based on 7 short sequence reads with distinct start points agreeing with the variant, while on average 70 sequence reads with distinct start points (counting positions on both of the mates and both strands) agreed with the variant for the Sanger confirmed mate-pair variants. Of the homozygous variants detected by Sanger sequencing $97 \%$, 96\% and 99\% were detected with the SOLiD mate-pair, SOLiD fragment and 454/FLX, respectively.

For the heterozygous SNPs, the confirmation rates by Sanger were $96 \%$ for the SOLiD matepair library (10 SNPs not detected with Sanger and 1 SNP homozygous with Sanger), 91\% for the SOLiD fragment library (28 SNPs not detected with Sanger and 1 SNP homozygous with Sanger) and 96\% for the 454/FLX (10 SNPs not detected with Sanger and 1 SNP homozygous with Sanger). For the 10 heterozygous SNPs not detected with the mate-pair library an average of 17 short sequence reads with distinct start points agreed with the variant compared to 54 for the Sanger confirmed variants. The 28 heterozygous SNPs not detected with the fragment library had on average 30 short sequence reads with distinct start points agreeing with the variant compared to 89 for the Sanger confirmed variants (counting positions on both strands). The 10 heterozygous SNPs not detected with 454/FLX were on average seen in 41 reads compared to 40 reads for the Sanger confirmed variants. For the Sanger detected heterozygous SNPs, 99\%, 98\% and 98\% were detected with the SOLiD 
mate-pair, SOLiD fragment and 454/FLX, respectively. The NOD2_04 SNP (see Supplementary Table S3 for IDs and other characteristics of identified SNPs) was only seen with the SOLiD mate-pair library, and not confirmed by Sanger, while ten SNPs (NOD2_01, NOD2_02, NOD2_03, NOD2_05, NOD2_06, NOD2_07, NOD2_08, NOD2_09, NOD2_10 and NOD2_11) were only seen with the SOLiD fragment library and not confirmed by Sanger. The NOD2_12 SNP was only detected with the 454/FLX and not confirmed by Sanger sequencing, in dbSNP a deletion is reported at this position (rs5816717) while in the pre-release from the 1000genomes project (http://www.1000genomes.org) a SNP with the same call as we observed was reported.

\section{Singleton and novel SNPS}

In total 19 SNPs not reported in dbSNP b130 (Sherry et al., 2001) were identified. Seven of these were confirmed by Sanger sequencing, all were singleton heterozygous SNPs, only observed in one individual. The private SNP ss196000735 is a non-synonymous coding SNP in exon 4 (leading to an amino acid change from alanine to glycine) and was detected with all technologies. The rest of the Sanger confirmed private variants were non-coding SNPs. Thirty-six of the 67 detected and Sanger-validated SNPs had previously been genotyped by the HapMap consortium (http://www.hapmap.org), and were included in the HapMap data release 27 (genotype data for one of these 36 SNPs were not reported in the European population dataset). Of the reported SNPs, two SNPs were reported to be monomorphic (minor allele frequency of " 0 ") while the rest had frequencies ranging from $3 \%$ to $48 \%$ in Utah residents with ancestry from northern and western Europe (see Supplementary Table S4). In the pre-release from the 1000genomes project (http://www.1000genomes.org), four of 
the SNPs (ss196000734, NOD2_08, ss196000736 and NOD2_12) currently not listed in dbSNP b130 were identified.

\section{Coverage simulation}

The coverage achieved varied between the samples and technologies (see Table 1), and to explore the importance of coverage depth, a simulation of lower coverages was performed. This was done irrespective of the local coverage across the region. In this coverage simulation experiment, the SNP detection rate at a coverage of $20 \mathrm{x}$ dropped to $78 \%, 83 \%$ and $84 \%$ compared to full coverage for the mate-pair, fragment and 454/FLX respectively (Figure 4 and 5). The numbers of misclassified SNPs at coverages above 20x were low (Figure 4). During the simulations, SNPs that were not observed at full coverage started to appear for all technologies, this was most pronounced for the SOLiD fragment library, while only one such SNP was seen for the 454/FLX. All these SNPs are listed as false positives in Figure 4. As the present project included several techniques these SNPs were compared to the results from the other technologies. Six SNPs from the fragment library simulation, one SNP from the mate-pair library simulation and one SNP from the 454/FLX simulation turned out to represent true SNPs seen in the other technologies and confirmed by Sanger, while the rest of the SNPs appearing during the simulations were not seen in any of the other technologies applied, i.e. true false positives. 


\section{Discussion}

Second generation sequencing has started to be the standard way of following up disease association findings from GWAS. These technologies have recently been used in several sequencing projects (Bentley et al., 2008; Wang et al., 2008; Wheeler et al., 2008; Ng et al., 2009; Choi et al., 2009). Comparsion of the different second generation technologies have previously been evaluated for mutational profiling in yeast (Smith et al., 2008) and a few human individuals (Harismendy et al., 2009). The present results report on a comparsion of resequencing performance of a target gene in individually selected patients. This sequencing scenario will be similar to what most researchers will face when they set out to resequence genetic regions discovered through GWAS.

For most of the samples included, we achieved saturating coverage in the target region, meaning that a further increase of the coverage beyond this point would not improve performance in terms of SNP detection. Importantly, the coverage figures used are the achieved coverage representing the reads that subsequently went into the SNP-calling pipelines of the SOLiD and 454/FLX systems, respectively. The coverage achieved is dependent upon the platform and the laboratory. Researchers planning a project need to take the platform and service provider efficacy into account when interpreting these numbers. Interestingly, from the coverage simulation, it seems that when using LR-PCR as the amplification method, a coverage depth of around 40x is necessary for all the technologies to achieve acceptable SNP detection rates. The uneven distribution of mappable reads implies that certain regions are oversequenced, a phenomenon which could preferably be reduced for cost reduction. With a more even representation of the different regions in the template, the average coverage needed for SNP detection may be lower. However, accurate equimolar 
mixing of the templates cannot entirely overcome this problem. When aiming at a target coverage of for example 100x, a large overrepresentation of one amplicon will reduce the relative representation of other regions, and could therefore lead to an impaired total performance in the sample. The over-representation is especially prominent at the end of the fragments, a problem that could partly be reduced when using blocked primers (Harismendy and Frazer, 2009).

In the simulation experiment, some of the SNPs originally detected as heterozygous changed their status to homozygous, a process related to the stochastic nature of the random removal of reads. In studies aiming at the detection of SNPs for further follow-up, this is not of critical importance, as it is merely the SNP detection that is of importance, and not the true genotype. For studies aiming at identifying haplotypes, inheritance patterns or phenotype correlations, the coverage should be of such depth that the distinction between homozygous and heterozygous SNPs is unambiguous. In addition, we noted that some SNPs not detected at full coverage, started to appear at lower coverages and represented true SNPs confirmed by Sanger. More troublesome was the appearance of true false positives, and such SNPs were evident with the SOLiD mate-pair and fragment libraries.

The number of detected homozygous and heterozygous SNPs and the sensitivity were comparable for the three technologies. There were only a few homozygous SNPs not confirmed by Sanger sequencing and only one of them was not detected at all, while the remaining SNPs were determined as heterozygous. For the heterozygous SNPs the number of false positive SNPs was considerably higher for the SOLiD fragment library compared to the 
SOLiD mate-pair library and the 454/FLX. These SNPs turned out to be supported by only a small number of short sequence reads with distinct start points and probably represent sequencing errors towards the end of the reads. Importantly, these SNPs are easy to sort out manually before further experiments are initiated. Thus, identified SNPs supported by a low number of unique starting points should be flagged as likely problematic ones.

As expected, given the small number of study subjects, most of the SNPs detected were already annotated in the public databases, and were common in the European population. NOD2 is one of the most studied genes in human complex diseases, and interestingly, we discovered as many as seven novel SNPs that were confirmed by Sanger sequencing. Six of these SNPs were intronic SNPs, while one exonic non-synonymous SNP (ss196000735) was seen in one patient with all technologies. Neither this SNP, nor the other two exonic SNPs that were not confirmed by Sanger (NOD2_04 and NOD2_09), were reported in an extensive investigation of the coding part of the NOD2 gene, a study in which 612 inflammatory bowel disease cases and 103 controls were resequenced (Lesage et al., 2002). This finding demonstrates that deep resequencing of even well-known disease genes in carefully selected individuals can yield novel rare or likely private variants of potential mechanistic importance not covered by GWAS (Bodmer and Bonilla, 2008).

In conclusion, we have demonstrated that second generation sequencing technologies are capable of resequencing target genes with reproducible results confirmed by Sanger sequencing. The uneven representation of the target region that we observed when using LRPCR renders it necessary to oversequence to get adequate coverage in all parts of the target 
region. Array-based enrichment (Summerer et al., 2009) and in-solution enrichment (Gnirke et al., 2009) could possibly solve this, however, more benchmarking experiments as herein described need to be performed for these enrichment methods as well. 


\section{Funding}

This work was supported by the German Ministry of Education and Research (BMBF) through the National Genome Research Network (NGFN), the popgen biobank and the European Community's Seventh Framework Programme (FP7/2007-2013) under grant agreement $\mathrm{n}^{\circ}$ [HEALTH-F4-2008-201418] entitled READNA. The project received infrastructure support through the DFG excellence cluster "Inflammation at Interfaces". E Melum and TH Karlsen were funded by the Norwegian PSC research center.

\section{Acknowledgments}

We thank all individuals with IBD, their families and physicians for their cooperation. We acknowledge the cooperation of the German Crohn and Colitis Foundation (Deutsche Morbus Crohn und Colitis Vereinigung e.V.), the BMBF competence network "IBD" and the contributing gastroenterologists. We wish to thank Lena Bossen, Anita Dietsch, Catharina von der Lancken, Ina Elena Baumgartner, Magda Depta, Melanie Friskovec, Susan Ehlers, Rainer Vogler and Kristian Holm for expert technical help. This study received infrastructure support from the DFG cluster of excellence "Inflammation at Interfaces". The Research Computing Services group at USIT, University of Oslo is acknowledged for making the Titan computing cluster available. We acknowledge Clarence Lee, Swati S. Ranade, and Fiona C. Hyland from Applied Biosystems for providing and supporting the SOLiD fragments run. We also thank Volker Strack and the support of the Operation groups of 454 Life Science for performing the the 454/FLX sequencing run. 
Reference List

Barrett JC, Hansoul S, Nicolae DL, Cho JH, Duerr RH, Rioux JD, Brant SR, Silverberg MS, Taylor KD, Barmada MM, Bitton A, Dassopoulos T, Datta LW, Green T, Griffiths AM, Kistner EO, Murtha MT, Regueiro MD, Rotter JI, Schumm LP, Steinhart AH, Targan SR, Xavier RJ, Libioulle C, Sandor C, Lathrop M, Belaiche J, Dewit O, Gut I, Heath S, Laukens D, Mni M, Rutgeerts P, Van Gossum A, Zelenika D, Franchimont D, Hugot JP, de Vos M, Vermeire S, Louis E, Cardon LR, Anderson CA, Drummond H, Nimmo E, Ahmad T, Prescott NJ, Onnie CM, Fisher SA, Marchini J, Ghori J, Bumpstead S, Gwilliam R, Tremelling M, Deloukas P, Mansfield J, Jewell D, Satsangi J, Mathew CG, Parkes M, Georges M, Daly MJ. 2008. Genome-wide association defines more than 30 distinct susceptibility loci for Crohn's disease. Nat Genet 40:955-962.

Bentley DR, Balasubramanian S, Swerdlow HP, Smith GP, Milton J, Brown CG, Hall KP, Evers DJ, Barnes CL, Bignell HR, Boutell JM, Bryant J, Carter RJ, Keira CR, Cox AJ, Ellis DJ, Flatbush MR, Gormley NA, Humphray SJ, Irving LJ, Karbelashvili MS, Kirk SM, Li H, Liu X, Maisinger KS, Murray LJ, Obradovic B, Ost T, Parkinson ML, Pratt MR, Rasolonjatovo IM, Reed MT, Rigatti R, Rodighiero C, Ross MT, Sabot A, Sankar SV, Scally A, Schroth GP, Smith ME, Smith VP, Spiridou A, Torrance PE, Tzonev SS, Vermaas EH, Walter K, Wu X, Zhang L, Alam MD, Anastasi C, Aniebo IC, Bailey DM, Bancarz IR, Banerjee S, Barbour SG, Baybayan PA, Benoit VA, Benson KF, Bevis C, Black PJ, Boodhun A, Brennan JS, Bridgham JA, Brown RC, Brown AA, Buermann DH, Bundu AA, Burrows JC, Carter NP, Castillo N, Chiara E Catenazzi, Chang S, Neil CR, Crake NR, Dada OO, Diakoumakos KD, DominguezFernandez B, Earnshaw DJ, Egbujor UC, Elmore DW, Etchin SS, Ewan MR, Fedurco M, Fraser LJ, Fuentes Fajardo KV, Scott FW, George D, Gietzen KJ, Goddard CP, Golda GS, Granieri PA, Green DE, Gustafson DL, Hansen NF, Harnish K, Haudenschild CD, Heyer NI, Hims MM, Ho JT, Horgan AM, Hoschler K, Hurwitz S, Ivanov DV, Johnson MQ, James T, Huw Jones TA, Kang GD, Kerelska TH, Kersey AD, Khrebtukova I, Kindwall AP, Kingsbury Z, Kokko-Gonzales PI, Kumar A, Laurent MA, Lawley CT, Lee SE, Lee X, Liao AK, Loch JA, Lok M, Luo S, Mammen RM, Martin JW, McCauley PG, McNitt P, Mehta P, Moon KW, Mullens JW, Newington T, Ning Z, Ling NB, Novo SM, O'Neill MJ, Osborne MA, Osnowski A, Ostadan O, Paraschos LL, Pickering L, Pike AC, Pike AC, Chris PD, Pliskin DP, Podhasky J, Quijano VJ, Raczy C, Rae VH, Rawlings SR, Chiva RA, Roe PM, Rogers J, Rogert Bacigalupo MC, Romanov N, Romieu A, Roth RK, Rourke NJ, Ruediger ST, Rusman E, Sanches-Kuiper RM, Schenker MR, Seoane JM, Shaw RJ, Shiver MK, Short SW, Sizto NL, Sluis JP, Smith MA, Ernest Sohna SJ, Spence EJ, Stevens K, Sutton N, Szajkowski L, Tregidgo CL, Turcatti G, Vandevondele S, Verhovsky Y, Virk SM, Wakelin S, Walcott GC, Wang J, Worsley GJ, Yan J, Yau L, Zuerlein M, Rogers J, Mullikin JC, Hurles ME, McCooke NJ, West JS, Oaks FL, Lundberg PL, Klenerman D, Durbin R, Smith AJ. 2008. Accurate whole human genome sequencing using reversible terminator chemistry. Nature 456:53-59.

Bodmer W, Bonilla C. 2008. Common and rare variants in multifactorial susceptibility to common diseases. Nat Genet 40:695-701. 
Choi M, Scholl UI, Ji W, Liu T, Tikhonova IR, Zumbo P, Nayir A, Bakkaloglu A, Ozen S, Sanjad S, Nelson-Williams C, Farhi A, Mane S, Lifton RP. 2009. Genetic diagnosis by whole exome capture and massively parallel DNA sequencing. Proc Natl Acad Sci U S A 106:19096-19101.

Croucher PJP, Mascheretti S, Hampe J, Huse K, Frenzel H, Stoll M, Lu T, Nikolaus S, Yang SK, Krawczak M, Kim WH, Schreiber S. 2003. Haplotype structure and association to Crohn's disease of CARD15 mutations in two ethnically divergent populations. Eur J Hum Genet 11:6-16.

Droege M, Hill B. 2008. The Genome Sequencer FLX System--longer reads, more applications, straight forward bioinformatics and more complete data sets. J Biotechnol 136:3-10.

Franke A, Hampe J, Rosenstiel P, Becker C, Wagner F, Hasler R, Little RD, Huse K, Ruether A, Balschun T, Wittig M, ElSharawy A, Mayr G, Albrecht M, Prescott NJ, Onnie CM, Fournier H, Keith T, Radelof U, Platzer M, Mathew CG, Stoll M, Krawczak M, Nurnberg P, Schreiber S. 2007. Systematic association mapping identifies NELL1 as a novel IBD disease gene. PLoS ONE 2:e691.

Gnirke A, Melnikov A, Maguire J, Rogov P, LeProust EM, Brockman W, Fennell T, Giannoukos G, Fisher S, Russ C, Gabriel S, Jaffe DB, Lander ES, Nusbaum C. 2009. Solution hybrid selection with ultra-long oligonucleotides for massively parallel targeted sequencing. Nat Biotechnol 27:182-189.

Harismendy O, Frazer K. 2009. Method for improving sequence coverage uniformity of targeted genomic intervals amplified by LR-PCR using Illumina GA sequencing-bysynthesis technology. Biotechniques 46:229-231.

Harismendy O, Ng PC, Strausberg RL, Wang X, Stockwell TB, Beeson KY, Schork NJ, Murray SS, Topol EJ, Levy S, Frazer KA. 2009. Evaluation of next generation sequencing platforms for population targeted sequencing studies. Genome Biol 10:R32.

Hindorff LA, Sethupathy P, Junkins HA, Ramos EM, Mehta JP, Collins FS, Manolio TA. 2009. Potential etiologic and functional implications of genome-wide association loci for human diseases and traits. Proc Natl Acad Sci U S A 106:9362-9367.

Hugot JP, Chamaillard M, Zouali H, Lesage S, Cezard JP, Belaiche J, Almer S, Tysk C, O'Morain CA, Gassull M, Binder V, Finkel Y, Cortot A, Modigliani R, Laurent-Puig P, Gower-Rousseau C, Macry J, Colombel JF, Sahbatou M, Thomas G. 2001. Association of NOD2 leucine-rich repeat variants with susceptibility to Crohn's disease. Nature 411:599-603.

Lesage S, Zouali H, Cezard JP, Colombel JF, Belaiche J, Almer S, Tysk C, O'Morain C, Gassull M, Binder V, Finkel Y, Modigliani R, Gower-Rousseau C, Macry J, Merlin F, Chamaillard M, Jannot AS, Thomas G, Hugot JP. 2002. CARD15/NOD2 mutational analysis and genotype-phenotype correlation in 612 patients with inflammatory bowel disease. Am J Hum Genet 70:845-857. 
McKernan K, Blanchard A, Kotler L, Costa G. 2006. Reagents, methods, and libraries for bead-based sequencing. Patent.

Metzker ML. 2010. Sequencing technologies - the next generation. Nat Rev Genet 11:31-46.

Nejentsev S, Walker N, Riches D, Egholm M, Todd JA. 2009. Rare Variants of IFIH1, a Gene Implicated in Antiviral Responses, Protect Against Type 1 Diabetes. Science 324:387-389.

Ng SB, Turner EH, Robertson PD, Flygare SD, Bigham AW, Lee C, Shaffer T, Wong M, Bhattacharjee A, Eichler EE, Bamshad M, Nickerson DA, Shendure J. 2009. Targeted capture and massively parallel sequencing of 12 human exomes. Nature 461:272-276.

Ogura Y, Bonen DK, Inohara N, Nicolae DL, Chen FF, Ramos R, Britton H, Moran T, Karaliuskas R, Duerr RH, Achkar JP, Brant SR, Bayless TM, Kirschner BS, Hanauer SB, Nunez G, Cho JH. 2001. A frameshift mutation in NOD2 associated with susceptibility to Crohn's disease. Nature 411:603-606.

Parkes M, Barrett JC, Prescott NJ, Tremelling M, Anderson CA, Fisher SA, Roberts RG, Nimmo ER, Cummings FR, Soars D, Drummond H, Lees CW, Khawaja SA, Bagnall R, Burke DA, Todhunter CE, Ahmad T, Onnie CM, McArdle W, Strachan D, Bethel G, Bryan C, Lewis CM, Deloukas P, Forbes A, Sanderson J, Jewell DP, Satsangi J, Mansfield JC, Cardon L, Mathew CG. 2007. Sequence variants in the autophagy gene IRGM and multiple other replicating loci contribute to Crohn's disease susceptibility. Nat Genet 39:830-832.

Raelson JV, Little RD, Ruether A, Fournier H, Paquin B, Van EP, Bradley WE, Croteau P, Nguyen-Huu Q, Segal J, Debrus S, Allard R, Rosenstiel P, Franke A, Jacobs G, Nikolaus S, Vidal JM, Szego P, Laplante N, Clark HF, Paulussen RJ, Hooper JW, Keith TP, Belouchi A, Schreiber S. 2007. Genome-wide association study for Crohn's disease in the Quebec Founder Population identifies multiple validated disease loci. Proc Natl Acad Sci U S A 104:14747-14752.

Rozen S, Skaletsky H. 2000. Primer3 on the WWW for general users and for biologist programmers. Methods Mol Biol 132:365-86.:365-386. 
Sanger F, Nicklen S, Coulson AR. 1977. Dna Sequencing with Chain-Terminating Inhibitors. Proc Natl Acad Sci U S A 74:5463-5467.

Schreiber S, Rosenstiel P, Albrecht M, Hampe J, Krawczak M. 2005. Genetics of Crohn disease, an archetypal inflammatory barrier disease. Nat Rev Genet 6:376-388.

Schuster SC. 2008. Next-generation sequencing transforms today's biology. Nat Methods 5:16-18.

Shendure J, Ji H. 2008. Next-generation DNA sequencing. Nat Biotechnol 26:1135-1145.

Shendure J, Porreca GJ, Reppas NB, Lin X, McCutcheon JP, Rosenbaum AM, Wang MD, Zhang K, Mitra RD, Church GM. 2005. Accurate multiplex polony sequencing of an evolved bacterial genome. Science 309:1728-1732.

Sherry ST, Ward MH, Kholodov M, Baker J, Phan L, Smigielski EM, Sirotkin K. 2001. dbSNP: the NCBI database of genetic variation. Nucleic Acids Res 29:308-311.

Smith DR, Quinlan AR, Peckham HE, Makowsky K, Tao W, Woolf B, Shen L, Donahue WF, Tusneem N, Stromberg MP, Stewart DA, Zhang L, Ranade SS, Warner JB, Lee CC, Coleman BE, Zhang Z, McLaughlin SF, Malek JA, Sorenson JM, Blanchard AP, Chapman J, Hillman D, Chen F, Rokhsar DS, McKernan KJ, Jeffries TW, Marth GT, Richardson PM. 2008. Rapid whole-genome mutational profiling using nextgeneration sequencing technologies. Genome Res 18:1638-1642.

Stephens M, Smith NJ, Donnelly P. 2001. A new statistical method for haplotype reconstruction from population data. Am J Hum Genet 68:978-989.

Summerer D, Wu H, Haase B, Cheng Y, Schracke N, Stahler CF, Chee MS, Stahler PF, Beier M. 2009. Microarray-based multicycle-enrichment of genomic subsets for targeted next-generation sequencing. Genome Res 19:1616-1621.

Wang J, Wang W, Li R, Li Y, Tian G, Goodman L, Fan W, Zhang J, Li J, Zhang J, Guo Y, Feng B, Li H, Lu Y, Fang X, Liang H, Du Z, Li D, Zhao Y, Hu Y, Yang Z, Zheng H, Hellmann I, Inouye M, Pool J, Yi X, Zhao J, Duan J, Zhou Y, Qin J, Ma L, Li G, Yang Z, Zhang G, Yang B, Yu C, Liang F, Li W, Li S, Li D, Ni P, Ruan J, Li Q, Zhu H, Liu D, Lu Z, Li N, Guo G, Zhang J, Ye J, Fang L, Hao Q, Chen Q, Liang Y, Su Y, San A, Ping C, Yang S, Chen F, Li L, Zhou K, Zheng H, Ren Y, Yang L, Gao Y, Yang G, Li Z, Feng X, Kristiansen K, Wong GK, Nielsen R, Durbin R, Bolund L, Zhang X, Li S, Yang H, Wang J. 2008. The diploid genome sequence of an Asian individual. Nature 456:60-65.

Weckx S, Del-Favero J, Rademakers R, Claes L, Cruts M, De JP, Van BC, De RP. 2005. novoSNP, a novel computational tool for sequence variation discovery. Genome Res 15:436-442.

Wheeler DA, Srinivasan M, Egholm M, Shen Y, Chen L, McGuire A, He W, Chen YJ, Makhijani V, Roth GT, Gomes X, Tartaro K, Niazi F, Turcotte CL, Irzyk GP, Lupski JR, Chinault C, Song XZ, Liu Y, Yuan Y, Nazareth L, Qin X, Muzny DM, Margulies 
M, Weinstock GM, Gibbs RA, Rothberg JM. 2008. The complete genome of an individual by massively parallel DNA sequencing. Nature 452:872-8U5.

Yeager M, Xiao NQ, Hayes RB, Bouffard P, Desany B, Burdett L, Orr N, Matthews C, Qi LQ, Crenshaw A, Markovic Z, Fredrikson KM, Jacobs KB, Amundadottir L, Jarvie TP, Hunter DJ, Hoover R, Thomas G, Harkins TT, Chanock SJ. 2008. Comprehensive resequence analysis of a $136 \mathrm{~kb}$ region of human chromosome $8 \mathrm{q} 24$ associated with prostate and colon cancers. Hum Genet 124:161-170. 
Figure 1-NOD2 genetic structure, long-range and ordinary PCR amplicons

Panel A and B show the physical localization of the NOD2 gene on chromosome 16q. Panel C shows the gene structure, with the open reading frame highlighted by thicker and dark blue boxes that correspond to exons. Positions are according to NCBI's build 36 . The coverage of each of the LR-PCR products (Panel D) is shown along with the Sanger PCR products (Panel E). The lower Panel F shows the identified SNPs and their positions, with nonsynonymous SNPs highlighted in red.

\section{Figure 2 - Average coverage across all samples and genomic GC-content}

The coverages for the SOLiD mate-pair, SOLiD fragment and 454/FLX are shown divided in $100 \mathrm{bp}$ bins across the sequenced region. All the samples sequenced are averaged within each of the technologies. The coverage for the different technologies is given relative to the average coverage seen using that technology. The GC content in the region is shown in the gray shaded area and was calculated according to the same $100 \mathrm{bp}$ bins that were used for the coverage calculation. Positions are according to NCBI's build 36.

\section{Figure 3 - Number of SNPs detected for each individual sample}

The upper Panel A shows the absolute number of homozygous SNPs detected for each individual sample, while the lower Panel B shows the corresponding number of heterozygous SNPs. All SNPs detected with the second generation technologies are included in the figure. 


\section{Figure 4 - Simulation of SNP detection at different coverage depths}

The graphs show the number of SNPs discovered at the specified coverage summed up for all individuals and divided into homozygous and heterozygous SNPs (as defined from full coverage call). False positives are SNPs that appeared during the simulation and that were not detected at full coverage for that specific technology irrespective of what the other technologies showed. The different genotype call class constitutes SNPs that were detected at full coverage but changed their genotype call during the simulation. The cleaned numbers are the total, homozygous and heterozygous SNPs detected, with removal of the false positives and SNPs changing their genotype call. Panel A shows simulation results from the SOLiD mate-pair library, Panel B from the SOLiD fragment library and Panel C shows the results from the 454/FLX runs. If the original coverage was below 100x for the 454/FLX runs (see Table 1), the maximum coverage achieved was used for the simulations above that coverage.

\section{Figure 5 - Comparison of simulation results}

The graphs show a comparison of the simulation experiments for the SOLiD mate-pair, SOLiD fragment and 454/FLX library. The number of SNPs for each of the technologies corresponds to the number of SNPs that were detected and that were identical to what was seen at full coverage. The gray line represents the total number of SNPs that were detected with any of the second generation technologies and subsequently confirmed by Sanger sequencing. 
Table 1 - Long-range PCR primers and the coverage achieved for each of the products

\begin{tabular}{|c|c|c|c|c|c|c|c|c|c|c|c|c|c|c|c|}
\hline \multirow[t]{2}{*}{ Fragment } & \multirow[t]{2}{*}{ Primer pair } & \multirow[t]{2}{*}{$\begin{array}{c}\text { Annealing } \\
\text { temperature }\end{array}$} & \multirow[t]{2}{*}{$\begin{array}{c}\text { Amplicon } \\
\text { length }\end{array}$} & \multirow{2}{*}{$\begin{array}{l}\text { Amplicon } \\
\text { start - end } \\
\text { (NCBI b36) }\end{array}$} & \multicolumn{11}{|c|}{$\begin{array}{l}\text { Average per base coverage for SOLiD mate-pair / SOLiD fragment / } 454 \text { FLX } \\
(\% \text { of base positions }<20 \mathrm{x})\end{array}$} \\
\hline & & & & & Sample 1 & Sample 2 & Sample 3 & Sample 4 & Sample 5 & Sample 6 & \begin{tabular}{|l|} 
Sample 7 \\
\end{tabular} & Sample 8 & Sample 9 & \begin{tabular}{|l|} 
Sample 10 \\
\end{tabular} & \begin{tabular}{|l|} 
Sample 11 \\
\end{tabular} \\
\hline 10 & $\begin{array}{l}\text { GGAGTGGGCCTTGGAGTC/ } \\
\text { GTCAGGACACTCTCGAAGC }\end{array}$ & $60^{\circ} \mathrm{C}$ & $5963 \mathrm{bp}$ & $\begin{array}{l}49285038- \\
49291000\end{array}$ & $\begin{array}{l}1621 / 6136 / 186 \\
(0 / 0 / 0)\end{array}$ & $\begin{array}{l}1724 / 6296 / 54 \\
(0 / 0 / 2)\end{array}$ & \begin{tabular}{l|l}
$1238 / 4466 / 139$ \\
$(0 / 1 / 0)$
\end{tabular} & \begin{tabular}{|l}
$1998 / 7623 / 20$ \\
$(0 / 0 / 41)$
\end{tabular} & $\begin{array}{l}1579 / 8481 / 51 \\
(0 / 1 / 2)\end{array}$ & $\begin{array}{l}254 / 14688 / 130 \\
(6 / 0 / 0)\end{array}$ & $\begin{array}{l}362 / 15589 / 116 \\
(4 / / 0 / 0)\end{array}$ & \begin{tabular}{|l|}
$206 / 13244 / 113$ \\
$(7 / 0 / 0)$
\end{tabular} & \begin{tabular}{|l|}
$979 / 14493 / 255$ \\
$(0 / / 0)$
\end{tabular} & $\begin{array}{l}869 / 9572 / 75 \\
(2 / 0 / 0)\end{array}$ & \begin{tabular}{|l|}
$359 / 17960 / 161$ \\
$(5 / / 0 / 0)$
\end{tabular} \\
\hline $\begin{array}{l}12 \\
13\end{array}$ & \begin{tabular}{|l|} 
GCTTTTCAGGCACAGAGGAG // \\
AAGTGTGGGAATCTTGCAC
\end{tabular} & $60^{\circ} \mathrm{C}$ & $9496 \mathrm{bp}$ & 49300418 & 196 & $\begin{array}{l}904 / 4728 / 76 \\
(0 / 0 / 1)\end{array}$ & $\begin{array}{l}819 / 2609 / 114 \\
(0 / 0 / 0)\end{array}$ & \begin{tabular}{|l|}
$1404 / 4022 / 20$ \\
$(0 / 0 / 55)$
\end{tabular} & $\begin{array}{l}624 / 3959 / 57 \\
(0 / 0 / 1)\end{array}$ & $01 / 143$ & & 3 & $\begin{array}{l}261 / 7602 / 259 \\
(1 / 0 / 0)\end{array}$ & $\begin{array}{l}145 / 6221 / 80 \\
(3 / 0 / 0)\end{array}$ & $\begin{array}{l}338 / 11339 / 188 \\
(1 / 0 / 0)\end{array}$ \\
\hline $\begin{array}{l}14 \\
15\end{array}$ & $\begin{array}{l}\text { CTGGCACTCTTTAGGGCTTG/ } \\
\text { GCTGCAACTGAATCCAGACA }\end{array}$ & $60^{\circ} \mathrm{C}$ & \begin{tabular}{|l|}
$10,722 \mathrm{bp}$ \\
\end{tabular} & \begin{tabular}{|l}
$49300077-$ \\
49310798
\end{tabular} & $\begin{array}{l}2059 / 4961 / 209 \\
(0 / 0 / 0)\end{array}$ & $\begin{array}{l}2205 / 5165 / 64 \\
(0 / 0 / 0)\end{array}$ & $\begin{array}{l}1301 / 3370 / 138 \\
(0 / 0 / 0)\end{array}$ & $\begin{array}{l}2970 / 5549 / 23 \\
(0 / 0 / 32)\end{array}$ & \begin{tabular}{|l|}
$1513 / 6016 / 59$ \\
$(0 / 0 / 0)$
\end{tabular} & $\begin{array}{l}297 / 15360 / 122 \\
(3 / 0 / 0)\end{array}$ & $\begin{array}{l}360 / 15632 / 126 \\
(1 / / 0 / 0)\end{array}$ & $\begin{array}{l}230 / 12559 / 114 \\
(4 / 0 / 0)\end{array}$ & $\begin{array}{l}639 / 13541 / 269 \\
(0 / 0 / 0)\end{array}$ & \begin{tabular}{|l|}
$317 / 9151 / 76$ \\
$(1 / 0 / 0)$
\end{tabular} & $\begin{array}{l}996 / 16578 / 170 \\
(0 / 0 / 0)\end{array}$ \\
\hline $\begin{array}{l}16 \\
17\end{array}$ & \begin{tabular}{|l|} 
GTTCTCCTAGCTGCCACACC $/$ \\
GTCCACACAACCGCTCCTAT
\end{tabular} & $60^{\circ} \mathrm{C}$ & $4276 \mathrm{bp}$ & $\begin{array}{l}49310609- \\
49314884\end{array}$ & $\begin{array}{l}1618 / 6776 / 220 \\
(0 / 0 / 0)\end{array}$ & $\begin{array}{l}1507 / 7434 / 65 \\
(0 / 0 / 0)\end{array}$ & $\begin{array}{l}1094 / 5051 / 162 \\
(0 / 0 / 0)\end{array}$ & $\begin{array}{l}1900 / 8959 / 25 \\
(0 / 0 / 25)\end{array}$ & \begin{tabular}{|l|}
$1041 / 8398 / 62$ \\
$(0 / 0 / 1)$
\end{tabular} & $\begin{array}{l}293 / 14109 / 133 \\
(3 / / 0 / 0)\end{array}$ & $\begin{array}{l}221 / 28576 / 141 \\
(5 / / 0 / 0)\end{array}$ & $\begin{array}{l}152 / 11552 / 135 \\
(8 / 0 / 0)\end{array}$ & \begin{tabular}{|l|}
$602 / 13348 / 353$ \\
$(2 / / 0)$
\end{tabular} & $\begin{array}{l}448 / 10136 / 83 \\
(2 / 0 / 0)\end{array}$ & \begin{tabular}{|l|}
$349 / 15215 / 169$ \\
$(2 / 0 / 0)$
\end{tabular} \\
\hline $\begin{array}{l}18 \\
19\end{array}$ & $\begin{array}{l}\text { CCTGGTGGGGAACAACATT I } \\
\text { AGAGCAGGGCTTTCAAACAA }\end{array}$ & $61^{\circ} \mathrm{C}$ & 8402 bp & $\begin{array}{l}49314713^{-} \\
49323114\end{array}$ & $\begin{array}{l}481 / 2853 / 144 \\
(0 / 0 / 0)\end{array}$ & $\begin{array}{l}273 / 3326 / 47 \\
(0 / 0 / 2)\end{array}$ & $\begin{array}{l}444 / 2908 / 125 \\
(0 / 0 / 0)\end{array}$ & \begin{tabular}{|l|}
$923 / 4421 / 19$ \\
$(0 / 0 / 69)$
\end{tabular} & \begin{tabular}{|l|}
$475 / 5043 / 50$ \\
$(0 / 0 / 2)$
\end{tabular} & $\begin{array}{l}91 / 10803 / 102 \\
(3 / 0 / 0)\end{array}$ & $\begin{array}{l}110 / 14252 / 143 \\
(3 / 0 / 0)\end{array}$ & \begin{tabular}{|l}
$47 / 6594 / 75$ \\
$(11 / 0 / 1)$
\end{tabular} & \begin{tabular}{|l|}
$74 / 9955 / 224$ \\
$(22 / 0 / 0)$
\end{tabular} & $\begin{array}{l}87 / 5645 / 59 \\
(4 / 0 / 2)\end{array}$ & \begin{tabular}{|l|}
$234 / 10997 / 155$ \\
$(2 / 0 / 0)$
\end{tabular} \\
\hline & $\begin{array}{l}\text { GCAGCGAATGCAGATATCAA / } \\
\text { GCGAAAGGAGACTCAACACC }\end{array}$ & $59^{\circ} \mathrm{C}$ & $3053 \mathrm{bp}$ & \begin{tabular}{|l|}
$49322284-$ \\
49325336
\end{tabular} & $\begin{array}{l}1289 / 5820 / 276 \\
(0 / 0 / 0)\end{array}$ & $\begin{array}{l}1530 / 9077 / 81 \\
(0 / 0 / 0)\end{array}$ & \begin{tabular}{|l|}
$1019 / 6399 / 212$ \\
$(0 / 0 / 0)$
\end{tabular} & \begin{tabular}{|l|}
$1834 / 9719 / 32$ \\
$(0 / 0 / 8)$
\end{tabular} & $\begin{array}{l}978 / 13294 / 109 \\
(1 / 0 / 0)\end{array}$ & $\begin{array}{l}191 / 18700 / 173 \\
(7 / 0 / 0)\end{array}$ & \begin{tabular}{|l|}
$192 / 16043 / 234$ \\
$(8 / 0 / 0)$
\end{tabular} & \begin{tabular}{|l|}
$104 / 13703 / 147$ \\
$(14 / 0 / 0)$
\end{tabular} & \begin{tabular}{|l|}
$572 / 30598 / 445$ \\
$(4 / 0 / 0)$
\end{tabular} & \begin{tabular}{|l|}
$464 / 12931 / 133$ \\
$(5 / 0 / 0)$
\end{tabular} & \begin{tabular}{|l|}
$306 / 19904 / 246$ \\
$(6 / 0 / 0)$
\end{tabular} \\
\hline
\end{tabular}

Primers used for generation of the Long-range PCR products and the coverage achieved for that product for the SOLiD mate-pair, SOLiD fragment library and the Roche 454/FLX. The numbers in parentheses list the percentages of base pair positions that had a coverage depth below 20x. 


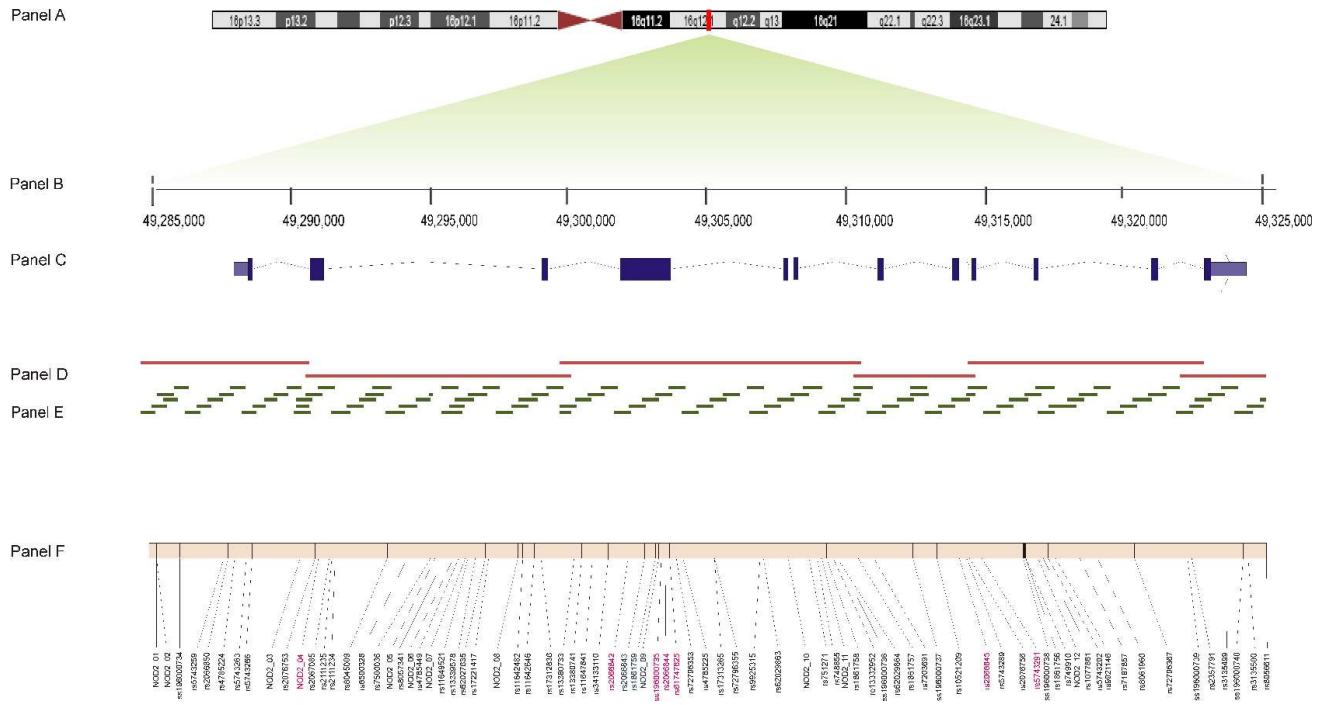

Figure 1 - NOD2 genetic structure, long-range and ordinary PCR amplicons Panel A and B show the physical localization of the NOD2 gene on chromosome 16q. Panel C shows the gene structure, with the open reading frame highlighted by thicker and dark blue boxes that correspond to exons. Positions are according to NCBI's build 36. The coverage of each of the LR-PCR products (Panel D) is shown along with the Sanger PCR products (Panel E). The lower Panel F shows the identified SNPs and their positions, with non-synonymous SNPs highlighted in red.

$283 \times 151 \mathrm{~mm}(600 \times 600 \mathrm{DPI})$

John Wiley \& Sons, Inc. 
Figure 2 - Average coverage across all samples and genomic GC-content The coverages for the SOLiD mate-pair, SOLiD fragment and 454/FLX are shown divided in $100 \mathrm{bp}$ bins across the sequenced region. All the samples sequenced are averaged within each of the technologies. The coverage for the different technologies is given relative to the average coverage seen using that technology. The GC content in the region is shown in the gray shaded area and was calculated according to the same 100 bp bins that were used for the coverage calculation. Positions are according to NCBI's build 36 .

$266 \times 200 \mathrm{~mm}(600 \times 600 \mathrm{DPI})$ 

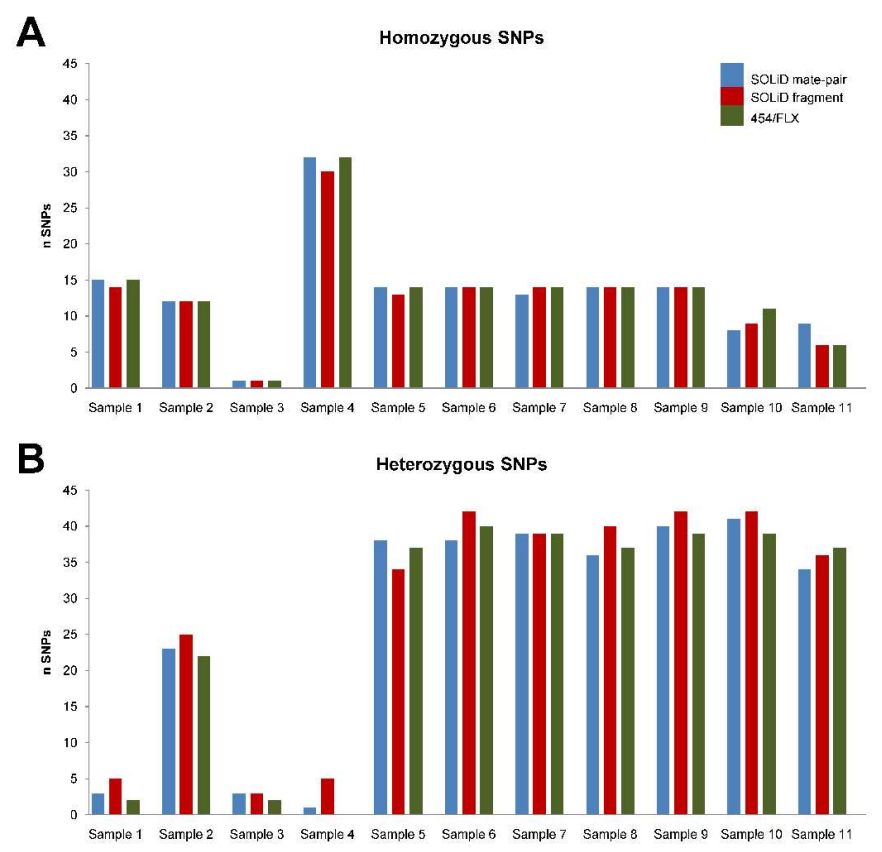

Figure 3 - Number of SNPs detected for each individual sample The upper Panel A shows the absolute number of homozygous SNPs detected for each individual sample, while the lower Panel B shows the corresponding number of heterozygous SNPs. All SNPs detected with the second generation technologies are included in the figure.

$266 \times 200 \mathrm{~mm}(600 \times 600 \mathrm{DPI})$ 


\section{A SOLiD mate-pair}

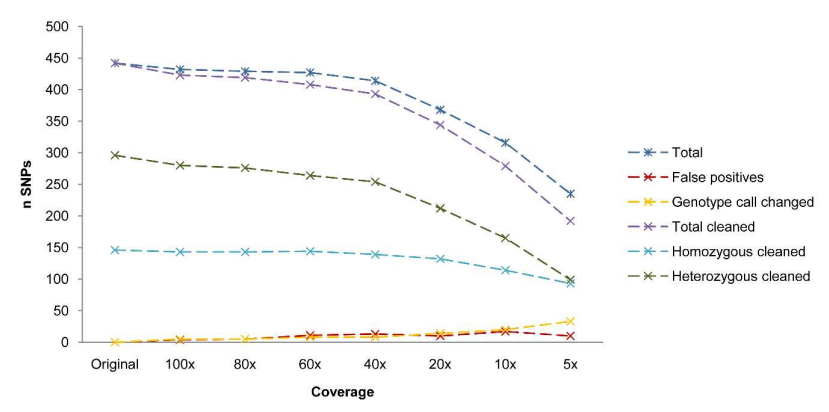

\section{B SOLiD fragment}

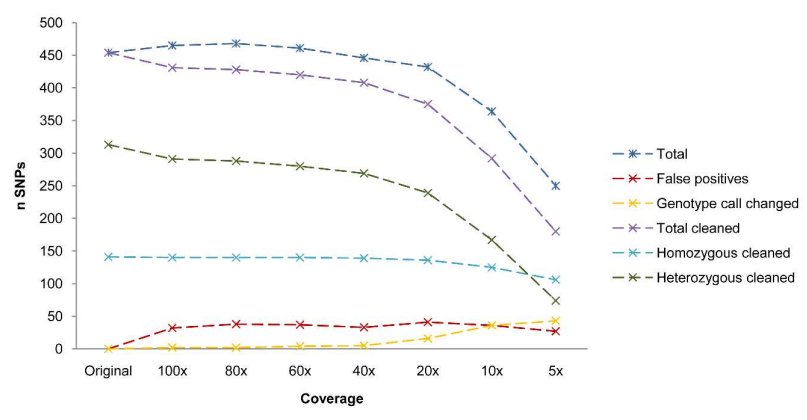

C $454 / F L X$

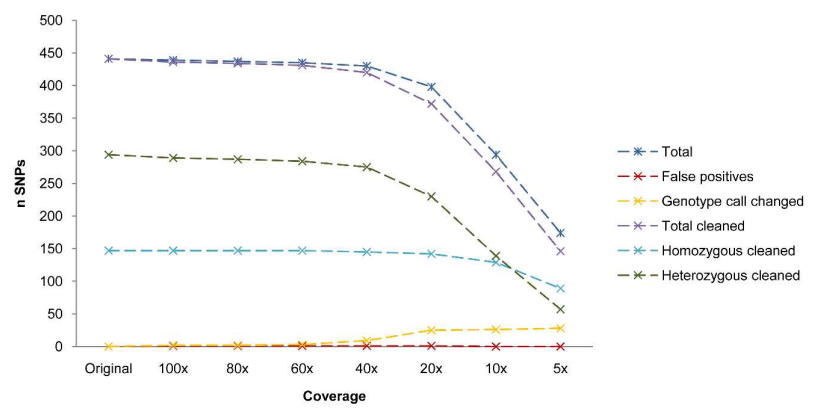

Figure 4 - Simulation of SNP detection at different coverage depths

The graphs show the number of SNPs discovered at the specified coverage summed up for all individuals and divided into homozygous and heterozygous SNPs (as defined from full coverage call). False positives are SNPs that appeared during the simulation and that were not detected at full coverage for that specific technology irrespective of what the other technologies showed. The different genotype call class constitutes SNPs that were detected at full coverage but changed their genotype call during the simulation. The cleaned numbers are the total, homozygous and heterozygous SNPs detected, with removal of the false positives and SNPs changing their genotype call. Panel A shows simulation results from the SOLiD mate-pair library, Panel B from the SOLiD fragment library and Panel $C$ shows the results from the 454/FLX runs. If the original coverage was below 100x for the 454/FLX runs (see Table 1), the maximum coverage achieved was used for the simulations above that coverage. 


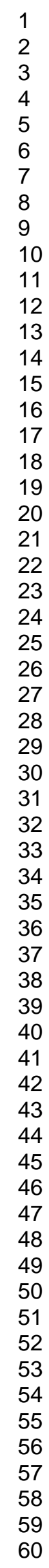

$165 \times 220 \mathrm{~mm}(600 \times 600 \mathrm{DPI})$

John Wiley \& Sons, Inc. 


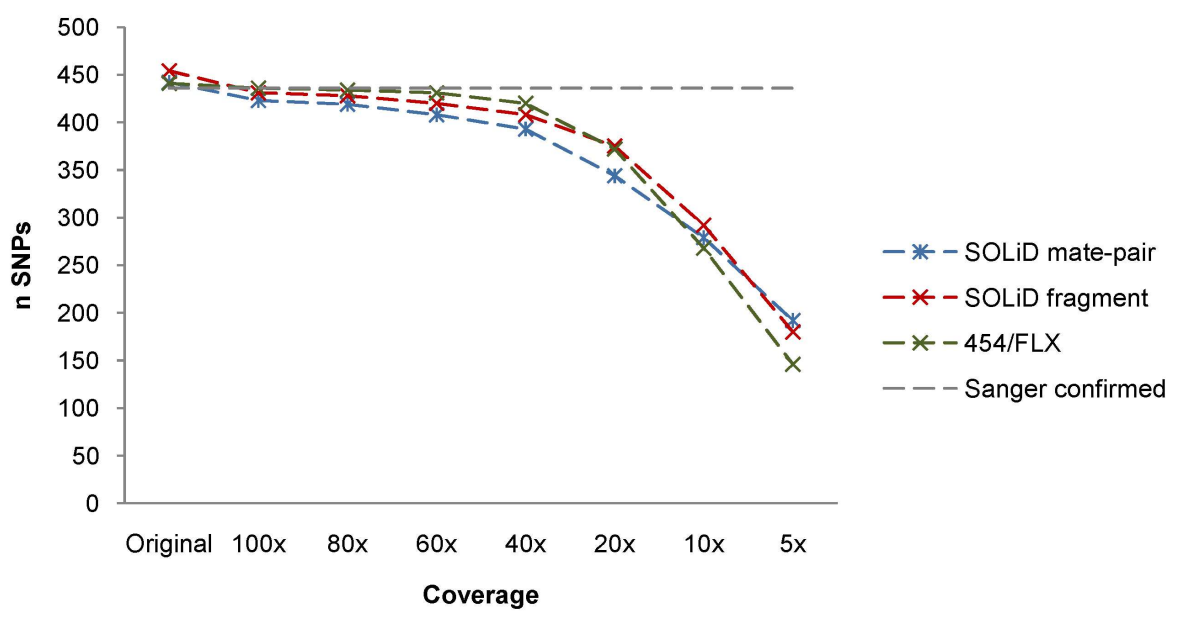

Figure 5 - Comparison of simulation results

The graphs show a comparison of the simulation experiments for the SOLiD mate-pair, SOLiD fragment and 454/FLX library. The number of SNPs for each of the technologies corresponds to the number of SNPs that were detected and that were identical to what was seen at full coverage. The gray line represents the total number of SNPs that were detected with any of the second generation technologies and subsequently confirmed by Sanger sequencing.

$120 \times 64 \mathrm{~mm}(600 \times 600 \mathrm{DPI})$ 


\title{
Supplementary Material
}

\section{SNP discovery performance of two second generation sequencing platforms in the NOD2 gene region}

\begin{abstract}
Authors: Espen Melum, Sandra May, Markus B. Schilhabel, Ingo Thomsen, Tom H. Karlsen, Philip Rosenstiel, Stefan Schreiber and Andre Franke
\end{abstract}


Supplementary Table S1 - Haplotype background of the included patients

\begin{tabular}{rll}
\hline Sample & Haplotype $\mathbf{1}\left(\mathbf{f}_{\mathbf{c o}} ; \mathbf{f}_{\mathrm{ca}} ; \mathbf{p}\right.$-value $)$ & Haplotype $\mathbf{2}\left(\mathbf{f}_{\mathbf{c o}} ; \mathbf{f}_{\mathbf{c a}} ; \mathbf{p}\right.$-value $)$ \\
\hline $\mathbf{1}$ & $\mathrm{H} 09(0.02 ; 0.02 ; \mathrm{ns})$ & $\mathrm{H} 09(0.02 ; 0.02 ; \mathrm{ns})$ \\
$\mathbf{2}$ & $\mathrm{H} 07(0.03 ; 0.01 ; \mathrm{p}=0.0319)$ & $\mathrm{H} 01(0.41 ; 0.29 ; \mathrm{p}<0.0001)$ \\
$\mathbf{3}$ & $\mathrm{H} 02(0.23 ; 0.17 ; \mathrm{p}=0.0133)$ & $\mathrm{H} 02(0.23 ; 0.17 ; \mathrm{p}=0.0133)$ \\
$\mathbf{4}$ & $\mathrm{H} 04(0.04 ; 0.11 ; \mathrm{p}<0.0001)$ & $\mathrm{H} 04(0.04 ; 0.11 ; \mathrm{p}<0.0001)$ \\
$\mathbf{5}$ & $\mathrm{H} 08(0.00 ; 0.04 ; \mathrm{p}<0.0001)$ & $\mathrm{H} 01(0.41 ; 0.29 ; \mathrm{p}<0.0001)$ \\
$\mathbf{6}$ & $\mathrm{H} 06(0.02 ; 0.02 ; \mathrm{ns})$ & $\mathrm{H} 01(0.41 ; 0.29 ; \mathrm{p}<0.0001)$ \\
$\mathbf{7}$ & $\mathrm{H} 06(0.02 ; 0.02 ; \mathrm{ns})$ & $\mathrm{H} 01(0.41 ; 0.29 ; \mathrm{p}<0.0001)$ \\
$\mathbf{8}$ & $\mathrm{H} 08(0.00 ; 0.04 ; \mathrm{p}<0.0001)$ & $\mathrm{H} 01(0.41 ; 0.29 ; \mathrm{p}<0.0001)$ \\
$\mathbf{9}$ & $\mathrm{H} 08(0.00 ; 0.04 ; \mathrm{p}<0.0001)$ & $\mathrm{H} 01(0.41 ; 0.29 ; \mathrm{p}<0.0001)$ \\
$\mathbf{1 0}$ & $\mathrm{H} 10(0.02 ; 0.01 ; \mathrm{ns})$ & $\mathrm{H} 01(0.41 ; 0.29 ; \mathrm{p}<0.0001)$ \\
$\mathbf{1 1}$ & $\mathrm{H} 09(0.02 ; 0.02 ; \mathrm{ns})$ & $\mathrm{H} 01(0.41 ; 0.29 ; \mathrm{p}<0.0001)$ \\
\hline
\end{tabular}

The table lists the haplotype background of the patients included in this study as determined by PHASE. The nomenclature used is the same as Croucher et al. reported. The number in parentheses represents the frequency of the haplotype in healthy controls $\left(\mathrm{f}_{\mathrm{co}}\right)$, in patients with Crohn's disease $\left(f_{\mathrm{co}}\right)$ and the significance level (p-value) for the association from that publication.

Croucher PJP, Mascheretti S, Hampe J, Huse K, Frenzel H, Stoll M, Lu T, Nikolaus S, Yang SK, Krawczak M, Kim WH, Schreiber S. 2003. Haplotype structure and association to Crohn's disease of CARD15 mutations in two ethnically divergent populations. Eur J Hum Genet 11:6-16. 
Supplementary Table S2 - Primers used for Sanger sequencing

\begin{tabular}{|c|c|c|c|}
\hline & Forward primer & Reverse primer & Genetic region \\
\hline Fragment 1 & GGAGTGGGCCTTGGAGTC & TAGGAGAGCAAACAGCTGGG & $49285038-49285533$ \\
\hline Fragment 2 & АААТССАТСССТTСССАGАC & ATGCTTCCAGCCTCAGATCC & 49285463-49285937 \\
\hline Fragment 3 & TCCCGATCACTCAGCCAT & ATCCTGCTTCCCAGCTTTGT & $49285838-49286329$ \\
\hline Fragment 4 & СССTGCTTCTGAGTTTGCTC & TCTCGTGTCTCATCCAGTGC & $49285656-49286184$ \\
\hline Fragment 5 & GAAAGGAATGGACAGCAATGA & CTATCGACACGGCCTTTGAA & $49286240-49286729$ \\
\hline Fragment 6 & ATGGCCCAGAGGTGGTTAAA & TTCATTTCCTCCAGGACACC & $49286655-49287136$ \\
\hline Fragment 7 & CCAGTGTTAGGAACCAGCCA & TGTCCTGAGTCTCTGCTGGG & $49287064-49287537$ \\
\hline Fragment 8 & AGTGTTAGGGAGGGAGAATGC & ССТТААСАТССТТССТСТТАСТСС & $49287466-49287924$ \\
\hline Fragment 9 & TGACAGATTTCGCCTGAAGA & GCCTACGTGTGAGCCATACA & $49287857-49288320$ \\
\hline Fragment 10 & TCCTGGTGTCCACAGAAGC & ATGTCCGAGGAGGACACTTG & $49288261-49288721$ \\
\hline Fragment 11 & CAGCCTAATGGGCTTTGATG & CCACTGGAAGCCAGGATCTA & 49288639-49289110 \\
\hline Fragment 12 & TGCTTAGATGTGGGCACAAG & CAGGGACATTCCCAGACACT & 49289039-49289507 \\
\hline Fragment 13 & ACTTGGCATCTGCTCCCTT & ATTGCTCTAAAGGTCCTGTCC & 49289468-49289908 \\
\hline Fragment 14 & AGAACGCTCGGAAACAACTT & TCAGGGAATTCATTCTCTTCG & 49289838-49290309 \\
\hline Fragment 15 & ATCCAGCCAGCATGAAAGAG & CCCAGAGAAGGCAAGAAACA & $49290252-49290733$ \\
\hline Fragment 16 & GCTGGTCTAGCGCTCCTG & GAGGTGGAAGCCCTCGTAGT & $49290551-49291054$ \\
\hline Fragment 17 & ACCAAGCATGGATATGGGAG & GTCCAGGACACTCTCGAAGC & $49290641-49291000$ \\
\hline Fragment 18 & CCAAGCATGGATATGGGAGT & TTCTGACAGGCCCAAGTACC & $49290642-49291131$ \\
\hline Fragment 19 & GTCGAGCTGCTGGTCTCAG & TTTACCTGCCTGGCTACCTTT & $49290950-49291506$ \\
\hline Fragment 20 & CTCATGAAGTCAGCCTGTGG & AAGGGAGACTGAGGCTGGA & $49291437-49291971$ \\
\hline Fragment 21 & AACCCTGTGTGATCTCAGGC & TGGTCTCAACTTCCCGATTT & $49291917-49292481$ \\
\hline Fragment 22 & TCCTGAGAGGCAGATGGAAC & GAAACTAAGGTCAGTCCAATAACGA & $49292420-49292978$ \\
\hline Fragment 23 & AGCAGAAGTGGTGCAGTCCT & CTTCAGCCCAGAAGTTCGAG & -49293459 \\
\hline Fragment 24 & AGGGGTTTGGAGAAGGTAGC & CCCAACCTTCAATGTTTGCT & $49293084-49293724$ \\
\hline Fragment 25 & TCACTGTGTCACCCAGGCT & TTGGGAAGACATGTTGGTTG & $49293384-49293950$ \\
\hline Fragment 26 & ATTTGGTGGCCTTCCCTTAG & GGAATCAGGCAATTCAGAGC & $49293870-49294451$ \\
\hline Fragment 27 & TCAGTTGGGCATAGCAGTTG & CCTGACCTTGTGATCCACCT & 49294316-49294942 \\
\hline Fragment 28 & GCCAAGAATAGTGGCATGTG & TACAAAGCAGCCCACTTCCT & 49294905-49295367 \\
\hline Fragment 29 & AGGAAGTGGGCTGCTTTGTA & GAGAGGATAATGGAATAATGCAATC & $49295348-49295430$ \\
\hline Fragment 30 & GGATTGATAGTTTGGCTGGG & ССTGTAAACTAATCAAGAACATTTCCC & $49295827-49296405$ \\
\hline Fragment 31 & GGCCATCATTTTCCTTCAGA & GCAAAAAGACACAGAGATGGAA & $49295863-49296524$ \\
\hline Fragment 32 & CCACCACCACACCCTTTAAGT & CAGTCAAACCTACCCCTTGC & 49296093-49296620 \\
\hline Fragment 33 & CCAAGAGGTACTTTCAATCTGGA & GGTAGACAAGTTTCACCCGC & $49296340-49296895$ \\
\hline Fragment 34 & TGGGCTCATGATACTCTTTGG & TCACCTTCTAGCACACGCTG & $49296807-49297377$ \\
\hline Fragment 35 & TACACACACTCCAGTCAGGG & CTGCTTCTGTTCCTGCCC & $49297306-49297866$ \\
\hline Fragment 36 & GATTAGACTCTGGCTGTGGCA & CCTAAGGTCCGGAGTTCCA & $49297811-49298346$ \\
\hline Fragment 37 & GGTTTCACCATGTTGTCCAG & CTTGCACATCCAACTGCCTA & $49298301-49298848$ \\
\hline Fragment 38 & TTGGGACATGCTTTGAAGGT & GCATCTCTCTTCCATCCAGAA & $49298608-49299181$ \\
\hline Fragment 39 & CGTTCAATTCACCATCCAAC & СССТCAATATATGGTAGCCCAA & $49299085-49299635$ \\
\hline Fragment 40 & AGCTTTCATTATCTCCCACACA & GCCAATGAGCTTTCCCTACA & $49299580-49300128$ \\
\hline Fragment 41 & CAAGCCTGGCACTCTTTAGG & CCTGGCCTGGTCTTACAGTG & $49300072-49300398$ \\
\hline Fragment 42 & CTGGCACTCTTTAGGGCTTG & TATTGCTGAGCTTTCTGCCC & $49300077-49300634$ \\
\hline Fragment 43 & GTCTAAGTTCAGGGATCCTGGT & CTCTGAGATGTGATAAAG & 49301143 \\
\hline Fragment 44 & GCTAGGTCCACCCAGATCAA & GGAGGAGTTCTAGATGACGGG & 49301069-49301617 \\
\hline Fragment 45 & GCCACTATGGCAGGACAGAT & CCAGACCTCCAGGACATTCT & $49301537-49302103$ \\
\hline Fragment 46 & GCTCAGTCTCGCTTCCTCAG & ATTCTTCAGCAGGTTGCCCT & $49302017-49302577$ \\
\hline Fragment 47 & CTGTCCAGACCCTGCTCTTC & ATCAGGGCTGACC & $528-49303064$ \\
\hline Fragment 48 & TGCTGCTACGTGTTCTCAGC & GGATGAGCCAGATGAACCC & $49303004-49303553$ \\
\hline Fragment 49 & AGCACTTCCACTCCATCCC & GCCAGGGTGGTTGTAGAGAT & $49303473-49304047$ \\
\hline Fragment 50 & ATTGACTGGCCTATGTGCTG & CCCAAGATGTGGAAAGAGGC & $49303972-49304516$ \\
\hline Fragment 51 & TTTGCCCTTTGGAGAATCTG & ITGTCATCTGTTTCCTC & $0-49305000$ \\
\hline Fragment 52 & TGATTATACCCATCATGGTCTTG & TGCACATTCTTATTTCTATCAGGG & $49304954-49305490$ \\
\hline Fragment 53 & TGAGTGGGAATTTGGAAACC & CTACGGCCTTGGCAGTTT & $49305429-49305977$ \\
\hline Fragment 54 & GCAATTACTGTCCTTGAGCGA & AGGTTGCAGGTCAT & 9306471 \\
\hline Fragment 55 & TTTTACTGTGTACCGGGTGCT & TGGAGCTGGCAATCAAGTATC & $49306759-49307339$ \\
\hline Fragment 56 & GTACAGTGGCACAATCTCGG & CTGTCTGCCACTCCTCTTGG & $49306880-49307437$ \\
\hline Fragment 57 & GGGAAGCTTTCAGATGATGTT & ATTCATCCCTGAAGTGCCAG & $49307368-49307917$ \\
\hline Fragment 58 & GTGCTCCATCTATGCAGGGT & AAACCTGGGCTCACCTCAAT & $49307860-49308400$ \\
\hline Fragment 59 & CTCCATGGCTAAGCTCCTTG & GGGCAATTTAAAGGCATCAG & $49308339-49308905$ \\
\hline Fragment 60 & GGTTTGCAGTCCATCTGGTT & GCAGGTGTGTAGGTATTGGGA & $49308808-49309391$ \\
\hline Fragment 61 & CAGTGGATGCCTGAAACCAT & TGCTATTCTGATCACGTGCC & $49309318-49309850$ \\
\hline Fragment 62 & TTTGAGCAACAATGAGGTCG & TACCCATCATCTTTCAGCCA & 49309699-49310226 \\
\hline Fragment 63 & CCACATGAAGGGCTGCAC & CCCTAGGCTTCCTGGGATAA & $49310158-49310736$ \\
\hline Fragment 64 & GTTCTCCTAGCTGCCACACC & GCTGCAACTGAATCCAGACA & $49310609-49310798$ \\
\hline Fragment 65 & GTTCTCCTAGCTGCCACACC & TAGTTTACTCAGCGGCTCCC & $49310609-49311187$ \\
\hline Fragment 66 & CTGCTGTGCAAACAGCGT & CTGAGGATCAGAGGGCTTCC & $49311109-49311680$ \\
\hline Fragment 67 & GAGGACAGTGCCCACGAG & GAAATGGGCTGGAACACCTA & $49311634-49312180$ \\
\hline Fragment 68 & CCTGGGACTGTAGGAAGAGAGA & GGTGCCCTAATAAATATGTGTTGAA & $49312125-49312705$ \\
\hline Fragment 69 & AGGTCACATCTGCCACATCA & GCAAGGTGGCTCACTTGTGT & $49312646-49313198$ \\
\hline Fragment 70 & CTGCTTGAGGTCACATCTGC & GGCTCACTTGTGTAATCCCAA & $49312639-49313191$ \\
\hline
\end{tabular}




\begin{tabular}{|c|c|c|c|}
\hline & Forward primer & Reverse primer & Genetic region \\
\hline Fragment 71 & CAGGTGATCCTCCСTCCTTT & GGTAACTGCCACCCACAAGT & $49313138-49313689$ \\
\hline Fragment 72 & TGTTATGGGCAGGTACTGGAG & САGСТССТСССТСТTСАССТ & $49313638-49314178$ \\
\hline Fragment 73 & TGGCTCAGGTAAGCTTCAGA & TGTCAGAGCAGGGAAAGACC & $49314110-49314686$ \\
\hline Fragment 74 & CAGGAGAGCACCACGAATTT & GTCCACACAACCGCTCCTAT & $49314619-49314884$ \\
\hline Fragment 75 & AACATTGGCAGTGTGGGTG & GCAGCAGCAGCAGTAATAGTAG & $49314726-49315302$ \\
\hline Fragment 76 & TGCCTGGCATATTTGTAAGTG & CTGATGCTCTCATAACAAGGTTC & $49315221-49315771$ \\
\hline Fragment 77 & TTTGCCACTTGGAATTTCTT & ССTACACTGCCTACATCCAGC & $49315720-49316269$ \\
\hline Fragment 78 & GAGGTTTAAACAAGGAAAGGGTT & GGATTCTCAATTCCAGGGAC & $49316206-49316758$ \\
\hline Fragment 79 & TGAGAGCCCTTGGAGTGAAT & TGAGCTCCAATTTCССТСАT & $49316705-49317268$ \\
\hline Fragment 80 & GGGAGGTGGTCCCAGTAAAT & CTAGGCAGATGCCACTTTCC & $49317154-49317736$ \\
\hline Fragment 81 & AGAGTGGTGAAGTGAGATGGG & TTCCTAGGACCACATTTGCC & $49317183-49317755$ \\
\hline Fragment 82 & GAAATGGGCTGGGAAGTTG & CCAGTCTAGGGTGCAATGGT & $49317617-49318528$ \\
\hline Fragment 83 & CCAGGCTTAGTTTCTGCCAA & TTTGCTCСААССТАСААСТСА & $49318229-49318784$ \\
\hline Fragment 84 & GATGAGTGCCTCAGTTGCCT & ATCCCTGCGAAACCATTACA & $49318667-49319253$ \\
\hline Fragment 85 & GCTGCAGGTGTTGCAGTTT & TGCAGTGGTGGTTCAAGAAG & $49319235-49319715$ \\
\hline Fragment 86 & СCTGCCAGTACACTССTСАTC & GGAGACAGGATAGGGCCAG & $49319659-49320226$ \\
\hline Fragment 87 & GAGCAACCTGGGAAACACAT & GAAGACCCACСАСТСТCTGC & $49320169-49320710$ \\
\hline Fragment 88 & GGGACACAGCCAAACCATA & ACAATGGTGAGCTTCAAGGA & $49320644-49321215$ \\
\hline Fragment 89 & CTGGCTAACTCCTGCAGTCTC & САCTGTGCAACCTGCTCCTA & $49321141-49321720$ \\
\hline Fragment 90 & ATTGGATCAGACCTTCTGCG & ATGAGTTGCCAAAGGGTCC & $49321657-49322214$ \\
\hline Fragment 91 & TCTTCTCAGATGGGCAAACC & ACTTTGCCCAGAACCTGATG & $49322131-49322693$ \\
\hline Fragment 92 & ATGATTGTGATAGCTCTGTGGC & AGAGCAGGGCTTTCAAACAA & $49322643-49323114$ \\
\hline Fragment 93 & GGGTCTGATGTTATTTGCTGC & TTCAGCCTTAGGCAGGACAG & $49322795-49323353$ \\
\hline Fragment 94 & TTGTGAGCAGGCTGTGAGTT & GGGTGCTGTAAGTGAAATATCAAA & $49323263-49323825$ \\
\hline Fragment 95 & TCCTTCCTCTGAGGCTGAAA & ACAAAGGCTTCAACATACATCA & $49323759-49324314$ \\
\hline Fragment 96 & AAATTAGGCCGTTCCTTCAAA & TTCCTCCGCTTCAAGTAGAAA & $49324245-49324808$ \\
\hline Fragment 97 & CTGGGCAACAAGAGTGGAAC & CCATAGACACACTCCCATGC & $49324697-49325246$ \\
\hline Fragment 98 & TGGTCACCCAGCAAGGTAAA & GCGAAAGGAGACTCAACACC & $49325143-49325336$ \\
\hline
\end{tabular}

The forward and reverse primers used for Sanger sequencing of the genetic region. The base pair positions that the fragments cover are listed according to NCBI's build 36. 


$\begin{array}{ll}\text { SNP } & \text { BP } \\ \text { NOD2_01 } & 49,285,092 \\ \text { NOD2_02 } & 49,285,093 \\ \text { ss196000734 } & 49,285,914 \\ \text { rs5743259 } & 49,287,589 \\ \text { rs2066850 } & 49,287,730 \\ \text { rs4785224 } & 49,287,947 \\ \text { rs5743263 } & 49,288,366 \\ \text { rs5743266 } & 49,288,597 \\ \text { NOD2_03 } & 49,290,339 \\ \text { rs2076753 } & 49,290,875 \\ \text { NOD2_04 } & 49,290,920 \\ \text { rs2067085 } & 49,291,360 \\ \text { rs2111235 } & 49,291,470 \\ \text { rs2111234 } & 49,291,534 \\ \text { rs8045009 } & 49,293,442 \\ \text { rs6500328 } & 49,294,157 \\ \text { rs7500036 } & 49,294,999 \\ \text { NOD2_05 } & 49,295,099 \\ \text { rs8057341 } & 49,295,481 \\ \text { NOD2_06 } & 49,295,958 \\ \text { rs4785449 } & 49,296,048 \\ \text { NOD2_07 } & 49,296,287 \\ \text { rs11649521 } & 49,296,331 \\ \text { rs13339578 } & 49,296,606 \\ \text { rs62027635 } & 49,296,951 \\ \text { rs17221417 } & 49,297,083 \\ \text { NOD2_08 } & 49,298,110 \\ \text { rs11642482 } & 49,298,265 \\ \text { rs11642646 } & 49,298,687 \\ \text { rs17312836 } & 49,298,963 \\ \text { rs13380733 } & 49,300,182 \\ \text { rs13380741 } & 49,300,439 \\ \text { rs11647841 } & 49,300,832 \\ \text { rs34133110 } & 49,301,420 \\ \text { rs2066842 } & 49,302,125 \\ \text { rs2066843 } & 49,302,700 \\ \text { rs1861759 } & 49,303,084 \\ \text { NOD209 } 09 & 49,303,168 \\ \text { ss196000735 } & 49,303,302 \\ \text { rs2066844 } & 49,303,427 \\ \text { rs61747625 } & 49,303,587 \\ \text { rs72796353 } & 49,303,795 \\ \text { rs4785225 } & 49,304,047 \\ \text { rs17313265 } & 49,305,205 \\ \text { rs72796355 } & 49,305,240 \\ \text { rs9925315 } & 49,306,875 \\ & \end{array}$

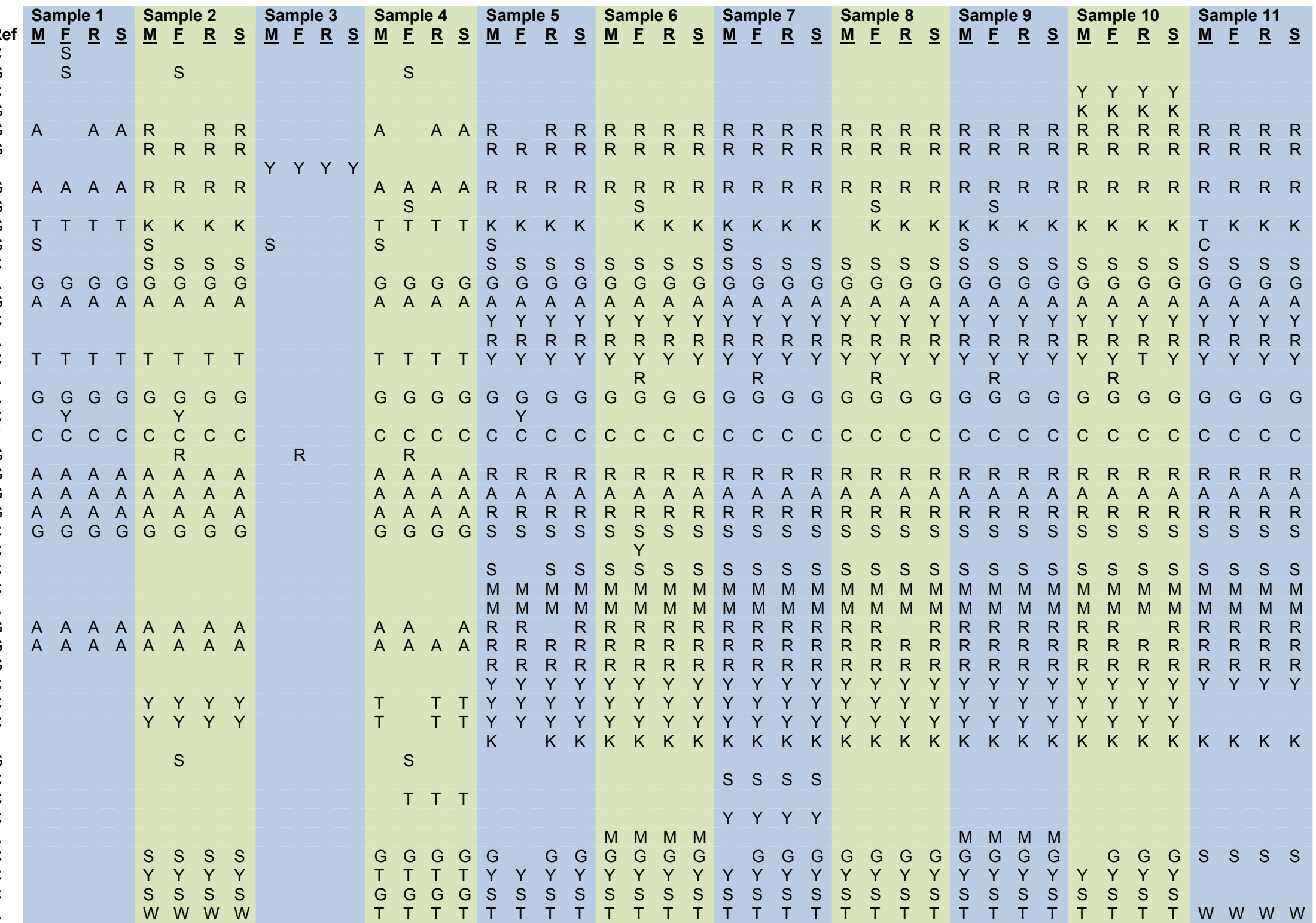




\begin{tabular}{|c|c|c|c|c|c|c|c|c|c|c|c|c|c|c|c|c|c|c|c|c|c|c|c|c|c|c|c|c|c|c|c|c|c|c|c|c|c|c|c|c|c|c|c|c|c|c|}
\hline \multirow{3}{*}{$\begin{array}{l}\text { SNP } \\
\text { rs62029863 } \\
\text { NOD2_10 } \\
\text { rs751271 }\end{array}$} & \multirow[b]{2}{*}{$\begin{array}{l}\text { BP } \\
49,306,909\end{array}$} & \multirow[b]{2}{*}{$\begin{array}{l}\text { Ref } \\
G\end{array}$} & \multicolumn{4}{|c|}{$\begin{array}{l}\text { Sample 1 } \\
\text { M F R S }\end{array}$} & \multicolumn{4}{|c|}{ Sample 2} & \multicolumn{4}{|c|}{ Sample 3} & \multicolumn{4}{|c|}{ Sample 4} & \multicolumn{4}{|c|}{ Sample 5} & \multicolumn{4}{|c|}{ Sample 6} & \multicolumn{4}{|c|}{ Sample 7} & San & mple & & & & Impl & & & & imple & e 10 & & Sar & mple & e 11 & \\
\hline & & & $\underline{M}$ & $\underline{F}$ & & $\underline{\mathbf{s}}$ & $\frac{\mathrm{M}}{\mathrm{K}}$ & $\frac{\mathrm{F}}{\mathrm{K}}$ & $\frac{\mathbf{R}}{\mathrm{K}}$ & $\frac{\mathbf{s}}{\mathrm{K}}$ & $\underline{M}$ & & $\underline{\mathbf{R}}$ & $\underline{\mathbf{s}}$ & $\frac{M}{T}$ & $\frac{\mathbf{F}}{\mathrm{T}}$ & & $\frac{\mathbf{s}}{T}$ & $\frac{\mathrm{M}}{\mathrm{K}}$ & $\frac{\mathrm{F}}{\mathrm{K}}$ & $\frac{\mathbf{R}}{\mathrm{K}}$ & $\frac{\mathrm{S}}{\mathrm{K}}$ & $\frac{\mathrm{M}}{\mathrm{K}}$ & $\frac{\mathrm{F}}{\mathrm{K}}$ & $\frac{R}{K}$ & $\frac{\mathrm{s}}{\mathrm{K}}$ & $\frac{M}{K}$ & $\frac{\mathrm{F}}{\mathrm{K}}$ & $\frac{\mathrm{R}}{\mathrm{K}}$ & $\frac{\mathrm{s}}{\mathrm{K}}$ & $\frac{M}{K}$ & $\begin{array}{l}\frac{F}{K} \\
M\end{array}$ & $\frac{\mathbf{R}}{\mathrm{K}}$ & $\frac{\mathbf{s}}{\mathrm{K}}$ & $\frac{M}{K}$ & $\begin{array}{l}\mathrm{F} \\
\mathrm{K} \\
\mathrm{M}\end{array}$ & $\frac{\mathbf{R}}{\mathrm{K}}$ & $\frac{\mathrm{S}}{\mathrm{K}}$ & $\frac{\mathrm{M}}{\mathrm{K}}$ & $\frac{\mathrm{F}}{\mathrm{K}}$ & $\frac{\mathbf{R}}{\mathrm{K}}$ & $\frac{\mathbf{s}}{\mathrm{K}}$ & $\underline{M}$ & $\underline{F}$ & $\underline{\mathbf{R}}$ & $\underline{\mathbf{s}}$ \\
\hline & $49,308,676$ & $\mathrm{~T}$ & & & & & $\mathrm{~K}$ & $\mathrm{~K}$ & $\mathrm{~K}$ & $\mathrm{~K}$ & & & & & G & G & G & G & G & G & G & G & G & G & G & G & G & G & G & G & G & G & G & G & G & G & G & G & G & G & G & G & $\mathrm{K}$ & K & $\mathrm{K}$ & $\mathrm{K}$ \\
\hline rs748855 & $49,308,899$ & A & & & & & & & & & & & & & & $c$ & & & $\mathrm{R}$ & $\mathrm{R}$ & $\mathrm{R}$ & $\mathrm{R}$ & $\mathrm{R}$ & $\mathrm{R}$ & $\mathrm{R}$ & $\mathrm{R}$ & $\mathrm{R}$ & $\mathrm{R}$ & $\mathrm{R}$ & $\mathrm{R}$ & $\mathrm{R}$ & $\mathrm{R}$ & $\mathrm{R}$ & $\mathrm{R}$ & $\mathrm{R}$ & $\mathrm{R}$ & $\mathrm{R}$ & $\mathrm{R}$ & $\mathrm{R}$ & $\mathrm{R}$ & $\mathrm{R}$ & $\mathrm{R}$ & $\mathrm{R}$ & $\mathrm{R}$ & $\mathrm{R}$ & $\mathrm{R}$ \\
\hline $\begin{array}{l}\text { NOD2_11 } \\
\text { rs1861758 }\end{array}$ & $\begin{array}{l}49,309,063 \\
49,309,288\end{array}$ & $\mathrm{G}$ & & & & & & & & & & & & & & $S$ & & & $\mathrm{R}$ & $\mathrm{R}$ & $\mathrm{R}$ & $\mathrm{R}$ & $\mathrm{R}$ & $\mathrm{R}$ & $\mathrm{R}$ & $\mathrm{R}$ & $\mathrm{R}$ & $\mathrm{R}$ & $\mathrm{R}$ & $\mathrm{R}$ & $\mathrm{R}$ & $\mathrm{R}$ & $\mathrm{R}$ & $\mathrm{R}$ & $\mathrm{R}$ & $\mathrm{R}$ & $\mathrm{R}$ & $\mathrm{R}$ & $\mathrm{R}$ & $\mathrm{R}$ & $\mathrm{R}$ & $\mathrm{R}$ & $\mathrm{R}$ & $\mathrm{R}$ & $\mathrm{R}$ & $\mathrm{R}$ \\
\hline rs13332952 & $49,309,473$ & G & & & & & $\mathrm{R}$ & $\mathrm{R}$ & $\mathrm{R}$ & $\mathrm{R}$ & & & & & A & A & A & A & A & A & A & A & A & A & A & A & A & A & A & A & A & A & A & A & A & A & A & A & $\mathrm{R}$ & $\mathrm{R}$ & $\mathrm{R}$ & $\mathrm{R}$ & $\mathrm{R}$ & $\mathrm{R}$ & $\mathrm{R}$ & $\mathrm{R}$ \\
\hline $\mathrm{s} 196000736$ & $49,309,610$ & C & & & & & & & & & $Y$ & Y & $Y$ & $Y$ & & & & & & & & & & & & & & & & & & & & & & & & & & & & & & & & \\
\hline s62029864 & $49,309,665$ & G & & & & & $\mathrm{R}$ & $\mathrm{R}$ & $\mathrm{R}$ & $\mathrm{R}$ & & & & & A & A & A & A & $\mathrm{R}$ & $\mathrm{R}$ & $\mathrm{R}$ & $\mathrm{R}$ & $\mathrm{R}$ & $\mathrm{R}$ & $\mathrm{R}$ & $\mathrm{R}$ & $\mathrm{R}$ & $\mathrm{R}$ & $\mathrm{R}$ & $\mathrm{R}$ & $\mathrm{R}$ & $\mathrm{R}$ & $\mathrm{R}$ & $\mathrm{R}$ & $R$ & $\mathrm{R}$ & $\mathrm{R}$ & $\mathrm{R}$ & & & & & & & & \\
\hline rs1861757 & $49,310,316$ & $\mathrm{~T}$ & & & & & & & & & & & & & & & & & $Y$ & $Y$ & $Y$ & $\mathrm{Y}$ & $\mathrm{Y}$ & $Y$ & $\mathrm{Y}$ & $Y$ & $Y$ & $Y$ & $Y$ & $Y$ & Y & $Y$ & $Y$ & $\mathrm{Y}$ & $Y$ & Y & $Y$ & $Y$ & Y & $Y$ & $Y$ & $Y$ & $Y$ & $Y$ & $Y$ & Y \\
\hline rs7203691 & $49,310,925$ & G & & & & & & & & & & & & & & & & & $\mathrm{R}$ & $\mathrm{R}$ & $\mathrm{R}$ & $\mathrm{R}$ & $\mathrm{R}$ & $\mathrm{R}$ & $\mathrm{R}$ & $\mathrm{R}$ & $\mathrm{R}$ & $\mathrm{R}$ & $\mathrm{R}$ & $\mathrm{R}$ & $\mathrm{R}$ & $\mathrm{R}$ & $\mathrm{R}$ & $\mathrm{R}$ & $\mathrm{R}$ & $\mathrm{R}$ & $\mathrm{R}$ & $\mathrm{R}$ & $\mathrm{R}$ & $\mathrm{R}$ & $\mathrm{R}$ & $\mathrm{R}$ & $\mathrm{R}$ & $\mathrm{R}$ & $\mathrm{R}$ & $\mathrm{R}$ \\
\hline ss196000737 & $49,312,786$ & $\mathrm{~T}$ & $\mathrm{~K}$ & $\mathrm{~K}$ & $\mathrm{~K}$ & $\mathrm{~K}$ & & & & & & & & & & & & & & & & & & & & & & & & & & & & & & & & & & & & & & & & \\
\hline s10521209 & $49,313,210$ & $\mathrm{~T}$ & & & & & & & & & & & & & & & & & $\mathrm{~K}$ & $\mathrm{~K}$ & $\mathrm{~K}$ & $\mathrm{~K}$ & $\mathrm{~K}$ & $\mathrm{~K}$ & $\mathrm{~K}$ & $\mathrm{~K}$ & $\mathrm{~K}$ & $\mathrm{~K}$ & $\mathrm{~K}$ & $\mathrm{~K}$ & $\mathrm{~K}$ & $\mathrm{~K}$ & $\mathrm{~K}$ & $\mathrm{~K}$ & $\mathrm{~K}$ & $\mathrm{~K}$ & $\mathrm{~K}$ & $\mathrm{~K}$ & $\mathrm{~K}$ & $\mathrm{~K}$ & $\mathrm{~K}$ & $\mathrm{~K}$ & $\mathrm{~K}$ & $\mathrm{~K}$ & $\mathrm{~K}$ & $\mathrm{~K}$ \\
\hline rs2066845 & $49,314,041$ & G & & & & & & & & & & & & & & & & & $\mathrm{s}$ & $\mathrm{s}$ & $\mathrm{s}$ & $\mathrm{s}$ & & & & & & & & & $\mathrm{s}$ & s & $\mathrm{s}$ & & $\mathrm{s}$ & s & s & & & & & & & & & \\
\hline 55743289 & $49,314,275$ & C & & & & & $\mathrm{Y}$ & $\mathrm{Y}$ & $\mathrm{Y}$ & $\mathrm{Y}$ & & & & & $\begin{array}{lll}T \\
T\end{array}$ & $\mathrm{~T}$ & $\begin{array}{lllll}T & \end{array}$ & $\mathrm{~T}$ & & & & & & & & & & & & & & & & & & & & & & & & & & & & \\
\hline s2076756 & $49,314,382$ & A & & & & & $\mathrm{R}$ & $\mathrm{R}$ & $\mathrm{R}$ & $\mathrm{R}$ & & & & & G & $\mathrm{G}$ & G & G & $\mathrm{R}$ & $\mathrm{R}$ & $\mathrm{R}$ & $\mathrm{R}$ & $\mathrm{R}$ & $\mathrm{R}$ & $\mathrm{R}$ & $\mathrm{R}$ & $\mathrm{R}$ & $\mathrm{R}$ & $\mathrm{R}$ & $\mathrm{R}$ & $\mathrm{R}$ & $\mathrm{R}$ & $\mathrm{R}$ & $\mathrm{R}$ & $\mathrm{R}$ & $\mathrm{R}$ & $\mathrm{R}$ & $\mathrm{R}$ & & & & & & & & \\
\hline rs5743291 & $49,314,777$ & G & & & & & & & & & & & & & & & & & & & & & & & & & & & & & & & & & & & & & $\mathrm{R}$ & $\mathrm{R}$ & A & $\mathrm{R}$ & & & & \\
\hline ss196000738 & $49,316,297$ & G & & & & & $\mathrm{R}$ & $\mathrm{R}$ & $\mathrm{R}$ & $\mathrm{R}$ & & & & & & & & & & & & & & & & & & & & & & & & & & & & & & & & & & & & \\
\hline rs1861756 & $49,316,339$ & $\mathrm{~T}$ & C & C & C & C & C & C & C & C & C & C & C & C & C & C & C & C & C & C & C & C & C & C & C & C & C & C & C & C & C & C & C & C & C & C & C & C & C & C & C & C & C & C & C & C \\
\hline 5749910 & $49,316,350$ & G & & & & & $\mathrm{R}$ & $\mathrm{R}$ & $\mathrm{R}$ & $\mathrm{R}$ & & & & & A & A & A & A & $\mathrm{R}$ & $\mathrm{R}$ & $\mathrm{R}$ & $\mathrm{R}$ & $\mathrm{R}$ & $\mathrm{R}$ & $\mathrm{R}$ & $\mathrm{R}$ & $\mathrm{R}$ & $\mathrm{R}$ & $\mathrm{R}$ & $\mathrm{R}$ & $\mathrm{R}$ & $\mathrm{R}$ & $\mathrm{R}$ & $\mathrm{R}$ & $\mathrm{R}$ & $\mathrm{R}$ & $\mathrm{R}$ & $\mathrm{R}$ & & & & & & & & \\
\hline NOD2 12 & $49,316,769$ & C & & & & & & & & & & & & & & & & & & & $\mathrm{M}$ & & & & $\mathrm{M}$ & & & & $\mathrm{M}$ & & & & $M$ & & & & $\mathrm{M}$ & & & & $\mathrm{M}$ & & & & M & \\
\hline rs1077861 & $49,317,048$ & $A$ & & & & & W & W & W & W & & & & & $\mathrm{T}$ & $\mathrm{T}$ & $\mathrm{T}$ & $\mathrm{T}$ & $T$ & $T$ & $\mathrm{~T}$ & $T$ & $\mathrm{~T}$ & $\mathrm{~T}$ & $\mathrm{~T}$ & $\mathrm{~T}$ & $\mathrm{~T}$ & $T$ & $\mathrm{~T}$ & $\begin{array}{lll}T \\
T\end{array}$ & $\mathrm{~T}$ & $\mathrm{~T}$ & $\mathrm{~T}$ & $\mathrm{~T}$ & $\mathrm{~T}$ & $\mathrm{~T}$ & $\mathrm{~T}$ & $T$ & W & W & W & w & W & W & W & W \\
\hline 55743292 & $49,317,232$ & $\mathrm{~T}$ & & & & & & & & & & & & & A & A & A & $A$ & & & & & & & & & & & & & & & & & & & & & & & & & & & & \\
\hline rs9921146 & $49,317,481$ & A & & & & & M & M & $\mathrm{M}$ & $\mathrm{M}$ & & & & & C & C & C & C & C & C & C & C & C & C & C & C & C & C & $\mathrm{C}$ & C & C & C & C & C & C & C & C & C & M & M & M & M & M & M & $\mathrm{M}$ & M \\
\hline rs7187857 & $49,318,339$ & A & & & & & $\mathrm{R}$ & $\mathrm{R}$ & $\mathrm{R}$ & $\mathrm{R}$ & & & & & $\mathrm{G}$ & $\mathrm{G}$ & G & G & G & $\mathrm{G}$ & G & G & G & G & G & G & G & $\mathrm{G}$ & G & G & G & $\mathrm{G}$ & G & G & G & G & G & G & $\mathrm{R}$ & $\mathrm{R}$ & $\mathrm{R}$ & $\mathrm{R}$ & $\mathrm{R}$ & $\mathrm{R}$ & $\mathrm{R}$ & $\mathrm{R}$ \\
\hline rs8061960 & $49,318,935$ & C & & & & & & & & & & & & & & & & & $Y$ & $Y$ & $Y$ & $Y$ & $Y$ & $Y$ & $Y$ & $Y$ & $Y$ & Y & $Y$ & $Y$ & $Y$ & $Y$ & $\mathrm{Y}$ & $Y$ & $Y$ & $Y$ & $Y$ & $\mathrm{Y}$ & Y & $\mathrm{Y}$ & $\mathrm{Y}$ & Y & $Y$ & $Y$ & $Y$ & $Y$ \\
\hline rs72796367 & $49,320,272$ & $\mathrm{~T}$ & & & & & & & & & & & & & & & & & & & & & Y & Y & $Y$ & Y & & & & & & & & & Y & Y & Y & Y & & & & & & & & \\
\hline ss196000739 & $49,322,271$ & G & $\mathrm{R}$ & $\mathrm{R}$ & $\mathrm{R}$ & R & & & & & & & & & & & & & & & & & & & & & & & & & & & & & & & & & & & & & & & & \\
\hline rs2357791 & $49,322,337$ & G & & & & & & & & & & & & & & & & & $\mathrm{R}$ & & $\mathrm{R}$ & $\mathrm{R}$ & $\mathrm{R}$ & $\mathrm{R}$ & $\mathrm{R}$ & $\mathrm{R}$ & $\mathrm{R}$ & $\mathrm{R}$ & $\mathrm{R}$ & $\mathrm{R}$ & $\mathrm{R}$ & $\mathrm{R}$ & $\mathrm{R}$ & $\mathrm{R}$ & $\mathrm{R}$ & $\mathrm{R}$ & & $\mathrm{R}$ & $\mathrm{R}$ & $\mathrm{R}$ & $\mathrm{R}$ & $\mathrm{R}$ & $\mathrm{R}$ & $\mathrm{R}$ & $\mathrm{R}$ & \\
\hline rs3135499 & $49,323,628$ & $A$ & & & & & & & & & & & & & & & & & $M$ & $M$ & $M$ & $M$ & $M$ & $M$ & $M$ & $M$ & $M$ & $M$ & $M$ & $M$ & $\mathrm{M}$ & $M$ & $M$ & $M$ & $M$ & M & M & $M$ & $M$ & $\mathrm{M}$ & $M$ & $M$ & $M$ & $M$ & $M$ & $M$ \\
\hline ss 196000740 & $49,324,255$ & G & & & & & & & & & & & & & & & & & & & & & $\mathrm{R}$ & $\mathrm{R}$ & $\mathrm{R}$ & $\mathrm{R}$ & & & & & & & & & & & & & & & & & & & & \\
\hline rs3135500 & $49,324,387$ & G & & & & & & & & & & & & & & & & & $\mathrm{R}$ & $\mathrm{R}$ & $\mathrm{R}$ & $\mathrm{R}$ & $\mathrm{R}$ & $\mathrm{R}$ & $\mathrm{R}$ & $\mathrm{R}$ & $\mathrm{R}$ & $\mathrm{R}$ & $\mathrm{R}$ & $\mathrm{R}$ & $\mathrm{R}$ & $\mathrm{R}$ & $\mathrm{R}$ & $\mathrm{R}$ & $\mathrm{R}$ & $\mathrm{R}$ & $\mathrm{R}$ & $\mathrm{R}$ & $\mathrm{R}$ & $\mathrm{R}$ & $\mathrm{R}$ & $\mathrm{R}$ & $\mathrm{R}$ & $\mathrm{R}$ & $\mathrm{R}$ & $\mathrm{R}$ \\
\hline rs8056611 & $49,325,148$ & A & & & & & & & & & & & & & & & & & G & G & G & G & G & G & G & G & G & G & G & G & G & G & G & G & G & G & G & G & $\mathrm{R}$ & $\mathrm{R}$ & $\mathrm{R}$ & G & G & $\mathrm{R}$ & $\mathrm{R}$ & 2 \\
\hline
\end{tabular}

Overview of all SNPs identified divided for the different technologies. The SNPs listed in the columns named $\underline{\mathbf{M}}, \underline{\mathbf{F}}, \underline{\mathbf{R}}$ and $\underline{\mathbf{S}}$ are from the samples sequenced with the SOLiD mate-pair library, SOLiD fragment library, Roche 454/FLX and Sanger, respectively. SNPs that had already been reported in the NCBI's database of SNPs (dbSNP 130) are listed with NCBI's dbSNP IDs (the rs-numbers) and the Sanger confirmed novel variants are listed with their temporary accession numbers (the ss-numbers). The rest of the SNPs are labeled NOD2_01 to NOD2_12. The coding non-synonymous SNPs are highlighted by red SNP-IDs. 


\begin{tabular}{|c|c|c|c|c|c|}
\hline & & & ele frec & & \\
\hline SNP & BP & CEU & CHB & JPT & YRI \\
\hline rs5743259 & $49,287,589$ & 0.00 & 0.00 & 0.00 & 0.00 \\
\hline rs4785224 & $49,287,947$ & 0.37 & 0.07 & 0.04 & 0.30 \\
\hline rs5743263 & $49,288,366$ & 0.03 & 0.00 & 0.00 & 0.00 \\
\hline rs5743266 & $49,288,597$ & 0.36 & 0.00 & 0.00 & 0.13 \\
\hline rs2076753 & $49,290,875$ & 0.34 & 0.00 & 0.01 & 0.02 \\
\hline rs2067085 & $49,291,360$ & 0.39 & 0.06 & 0.02 & 0.25 \\
\hline rs2111235 & $49,291,470$ & 0.75 & 0.35 & 0.28 & 0.67 \\
\hline rs2111234 & $49,291,534$ & 0.73 & 0.29 & 0.27 & 0.63 \\
\hline rs6500328 & $49,294,157$ & 0.38 & 0.30 & 0.24 & 0.50 \\
\hline rs8057341 & $49,295,481$ & 0.72 & 0.24 & 0.22 & 0.83 \\
\hline rs11649521 & $49,296,331$ & 0.36 & 0.00 & 0.00 & 0.00 \\
\hline rs13339578 & $49,296,606$ & 0.74 & 0.30 & 0.26 & 0.56 \\
\hline rs17221417 & $49,297,083$ & 0.35 & 0.00 & 0.00 & 0.01 \\
\hline rs11642646 & $49,298,687$ & 0.38 & 0.26 & 0.19 & 0.16 \\
\hline rs17312836 & $49,298,963$ & 0.38 & 0.26 & 0.19 & 0.15 \\
\hline rs13380733 & $49,300,182$ & $\mathrm{n} / \mathrm{a}$ & 0.00 & 0.00 & 0.00 \\
\hline rs13380741 & $49,300,439$ & 0.36 & 0.00 & 0.00 & 0.06 \\
\hline rs11647841 & $49,300,832$ & 0.39 & 0.23 & 0.20 & 0.17 \\
\hline rs2066842 & $49,302,125$ & 0.34 & 0.00 & 0.01 & 0.01 \\
\hline rs2066843 & $49,302,700$ & 0.33 & 0.00 & 0.00 & 0.01 \\
\hline rs1861759 & $49,303,084$ & 0.37 & 0.14 & 0.15 & 0.16 \\
\hline rs 4785225 & $49,304,047$ & 0.71 & 0.29 & 0.22 & 0.55 \\
\hline rs17313265 & $49,305,205$ & 0.34 & 0.02 & 0.04 & 0.04 \\
\hline rs751271 & $49,308,676$ & 0.71 & 0.24 & 0.23 & 0.54 \\
\hline rs748855 & $49,308,899$ & 0.37 & 0.21 & 0.18 & 0.16 \\
\hline rs1861758 & $49,309,288$ & 0.37 & 0.21 & 0.17 & 0.21 \\
\hline rs1861757 & $49,310,316$ & 0.39 & 0.18 & 0.16 & 0.07 \\
\hline rs10521209 & $49,313,210$ & 0.39 & 0.21 & 0.17 & 0.17 \\
\hline rs5743289 & $49,314,275$ & 0.23 & 0.00 & 0.00 & 0.00 \\
\hline rs2076756 & $49,314,382$ & 0.32 & 0.00 & 0.00 & 0.01 \\
\hline rs5743291 & $49,314,777$ & 0.10 & 0.00 & 0.00 & 0.00 \\
\hline rs1861756 & $49,316,339$ & 1.00 & 1.00 & 1.00 & 1.00 \\
\hline rs1077861 & $49,317,048$ & 0.72 & 0.21 & 0.17 & 0.18 \\
\hline rs3135499 & $49,323,628$ & 0.40 & 0.25 & 0.23 & 0.57 \\
\hline rs3135500 & $49,324,387$ & 0.39 & 0.24 & 0.22 & 0.57 \\
\hline rs8056611 & $49,325,148$ & 0.48 & 0.32 & 0.30 & 0.77 \\
\hline
\end{tabular}

The frequencies of the alternate allele for the detected SNPs are shown for the four HapMap populations (CEU: CEPH (Utah residents with ancestry from northern and western Europe), CHB: Han Chinese in Beijing, China, JPT: Japanese in Tokyo, Japan, YRI: Yoruba in Ibadan, Nigeria). The frequencies are based on frequencies for SNPs reported in the HapMap data release 27. 